\title{
Living and dead foraminiferal assemblage from the supratidal sand Japsand, North Frisian Wadden Sea: distributional patterns and controlling factors
}

\author{
Sarina Schmidt ${ }^{*}$ (i) and Joachim Schönfeld
}

\begin{abstract}
Supratidal sands are vitally important for coastal defence in the German Wadden Sea. They are less affected by human activities than other areas as they are located far off the mainland shore, touristical and commercial activities are generally prohibited. Therefore, supratidal sands are of high ecological interest. Nevertheless, the faunal inventory and distribution pattern of microorganisms on these sands were studied very little. The composition of living and dead foraminiferal assemblages was therefore investigated along a transect from the supratidal sand Japsand up to Hallig Hooge. Both assemblages were dominated by calcareous foraminifera of which Ammonia batava was the most abundant species. Elphidium selseyense and Elphidium williamsoni were also common in the living assemblage, but Elphidium williamsoni was comparably rare in the dead assemblage. The high proportions of Ammonia batava and Elphidium selseyense in the living assemblage arose from the reproduction season that differed between species. While Ammonia batava and Elphidium selseyense just finished their reproductive cycles, Elphidium williamsoni was just about to start. This was also confirmed by the size distribution patterns of the different species. The dead assemblage revealed 20 species that were not found in the living assemblage of which some were reworked from older sediments (e.g., Bucella frigida) and some were transported via tidal currents from other areas in the North Sea (e.g., Jadammina macrescens). The living foraminiferal faunas depicted close linkages between the open North Sea and the mainland. Key species revealing exchange between distant populations were Haynesina germanica, Ammonia batava and different Elphidium species. All these species share an opportunistic behaviour and are able to inhabit a variety of different environments; hence, they well may cope with changing environmental conditions. The benthic foraminiferal association from Japsand revealed that transport mechanisms via tides and currents play a major ecological role and strongly influence the faunal composition at this site.
\end{abstract}

Keywords: German Wadden Sea, Benthic foraminifera, Assemblage analysis, Faunal connectivity, Biometry

\section{Introduction}

The North Frisian supratidal sands Japsand, Norderoogsand and Süderoogsand are located at the seaward border of the German Wadden Sea and North Sea (Fig. 1a). They

*Correspondence: sschmidt@geomar.de

GEOMAR Helmholtz Centre for Ocean Research, Wischhofstraße 1-3, 24148 Kiel, Germany are highly significant for coastal defence because most of the energy of the incoming deep-water waves from the North Sea is dissipated along the seaward slope of these sands $[1,2]$. Therefore, the sands are essential for the stability and protection of the North Frisian shoreline.

Besides their protective function, the North Frisian supratidal sands are uninhabited by humans and therefore ideal resting places for birds and seals. As such, 


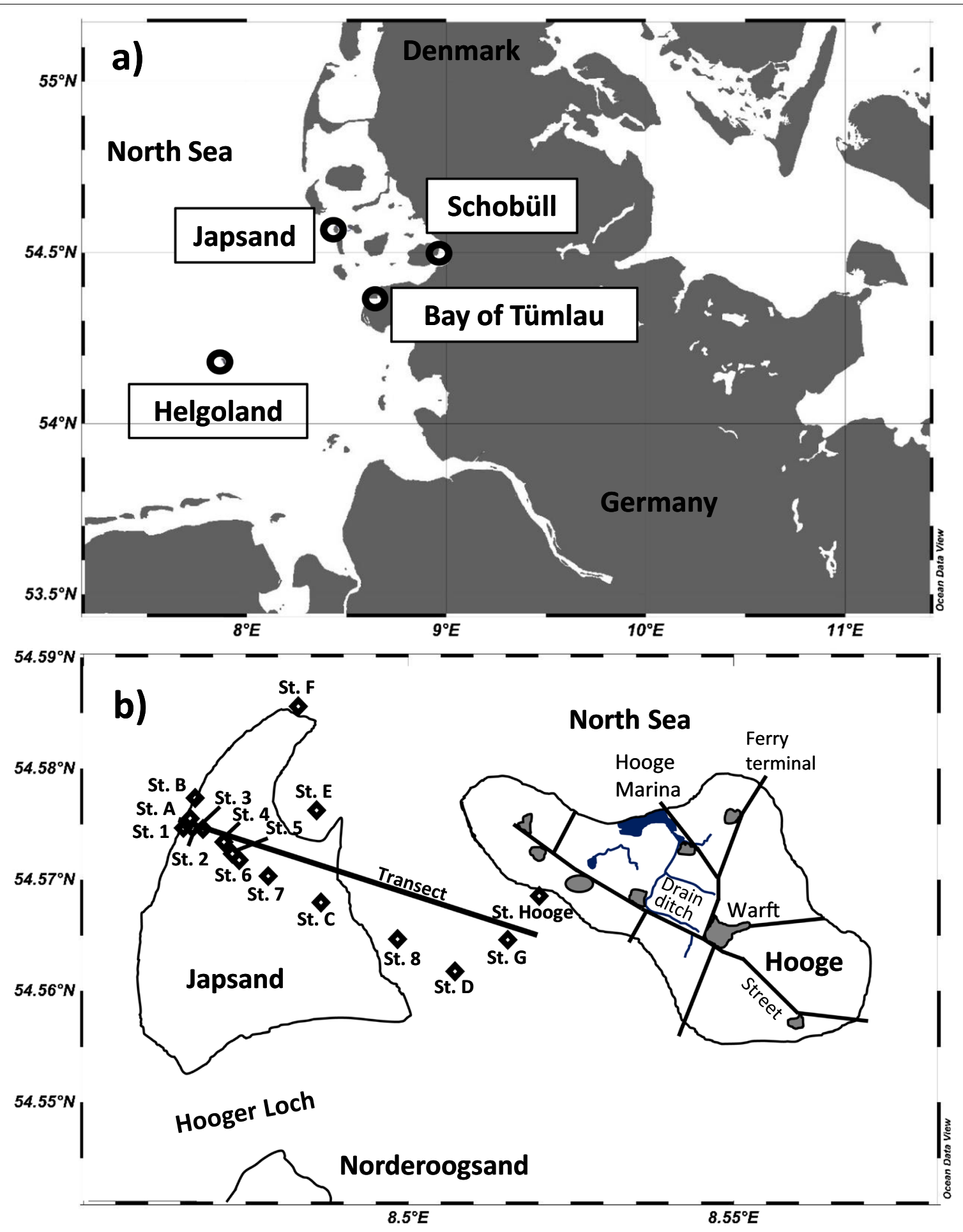

Fig. 1 Locations of the Japsand and comparative sites (Helgoland, Schobüll and Bay of Tümlau) in the German North Sea (a). Location of the individual stations in the study area (b). The outline of the Japsand represents the mean high water level. The map was drawn after satellite images from 2019 and the geological map of Schleswig Holstein (1:250 000, ed. 2012 @ Landesvermessungsamt Schleswig-Holstein) and personal observations 
the sands have a high ecological relevance. The faunal inventory and distribution pattern of smaller organisms on supratidal sands has attracted less attention though. In particular, little is known about benthic foraminiferal associations, their connectivity, i.e. relationship and exchange with faunas from the open North Sea and the intertidal zone [3], which both are well investigated [e.g., 4-8]. Foraminifera are an important constituent of the benthic meiofauna and play a key role in benthic biogeochemical cycles [e.g., 9-11]. The aim of this study was to address how foraminiferal communities were connected over a wide range of facies and distance. In this context, barrier sands like the Japsand act as connectors between the shelf sea environments and the intertidal zone at the coast and can reveal new insights into the interaction, i.e. linkage by exchange of different foraminiferal communities. Therefore, we investigated the foraminiferal assemblages from Japsand and compared them with associations from the open North Sea close to Helgoland and near shore associations from Schobüll and Bay of Tümlau (Fig. 1a).

A growing literature has demonstrated that benthic foraminifera were reliable indicators for environmental and paleoenvironmental conditions as well as for the ecosystem status in general [e.g., 12-22]. Furthermore, they are highly sensitive to small changes in critical environmental parameters like salinity $[23,24]$, temperature [25, 26] or carbonate system parameters [27-30]. Their short generation time and good preservation potential of dead, empty tests [31-33], render benthic foraminifera a prominent tool for reconstructing environmental parameters in the present and past [34]. This particularly holds true under the ongoing anthropogenic pressure, like global warming and pollution, as foraminiferal assemblage structures are going to change dramatically [35-38]. Even though the sensitivity living species for certain environmental parameters have been well constrained, the living fauna represents only a snapshot in time. Therefore, dead foraminiferal assemblages comprising multiple generations have often been used to calibrate palaeoproxies for the reconstruction of past environmental conditions, for instance the sea level [39-44]. However, dissolution [31, 45-47] or reworking [48] may well have biased the composition of the dead assemblage, hence making it possible that the living fauna and their driving environmental factors were not correctly mirrored anymore. A comparison of the living faunas and modern dead assemblages from Japsand was attempted to constrain processes that potentially have changed the foraminiferal assemblage composition on sand flats and near shore sands. Size distribution analyses of the most abundant species may reveal whether cohorts of juveniles are present in the living fauna, hence recent reproduction has taken place.
Differences in size distribution of living and dead assemblages allow to constrain the timeframe that is necessary to transpose recent changes to the dead and subfossil assemblage composition.

\section{Regional setting}

The Wadden Sea covers an area of approximately $10,000 \mathrm{~km}^{2}$ and extends from the city of Den Helder in the Netherlands up north to Blåvand headland in Denmark. The area is shaped by tides and currents, hosts a dynamic shallow water body variable in salinity and temperature, and sustains a high primary production and biodiversity. The German sector of the Wadden Sea is characterized by extensive tidal mud flats, numerous inlets, four major estuaries, sandy barrier islands and sands (Fig. 1a).

This study focuses on Japsand, which is located $2 \mathrm{~km}$ west of Hallig Hooge island (Fig. 1b). Japsand, Norderoogsand and Süderoogsand form a chain of supratidal barrier sands with a north-south extension of ca. $19 \mathrm{~km}$ and a width ranging from $4 \mathrm{~km}$ in the South to $1 \mathrm{~km}$ in the North $[1,2]$. Japsand is the smallest of these barrier sands, with a north-south extension of $3 \mathrm{~km}$, a westeast extension of ca. $2 \mathrm{~km}$ at maximum and an area of ca. $3 \mathrm{~km}^{2}$. All barriers moved continuously eastwards. The displacement velocity of Japsand has been estimated to 15-27 $\mathrm{m} \mathrm{a}^{-1}$ [2] (Fig. 2a), an amalgamation with Hallig Hooge will hence take place in the future. The tidal channel Hooger Loch separates Japsand and Norderoogsand, and the strong tidal currents inhibited a merger of both barrier sands. Mean tidal range is approximately $2.7 \mathrm{~m}$. Japsand is not regularly submerged during spring tides. The mean wave height is $0.75 \mathrm{~m}$, the prevailing wind and wave directions are west to northwest [1]. Extensive storm floods during autumn and winter episodically caused a flooding of the whole area of the barrier sand.

\section{Material and methods}

Foraminiferal samples were collected at 16 stations along an east-western transect from Hallig Hooge to the western edge of Japsand on two sampling campaigns in Mai and July 2019 (Fig. 1b, Table 1). All stations were in the intertidal zone. They were either submerged or showed evidences for recent flooding in terms of wet diatom mats, macroalgae, or living macrofauna. The exact locations were chosen as being representative for the prevailing sedimentary environment that we observed at certain intervals of the transect. The surface structures, algae, macrofauna and sediment properties were described. The latter are of particular importance as different substrates may house different foraminiferal associations.

The surface sediment was sampled using a handheld push corer of $54 \mathrm{~mm}$ inner diameter. Supernatant water 


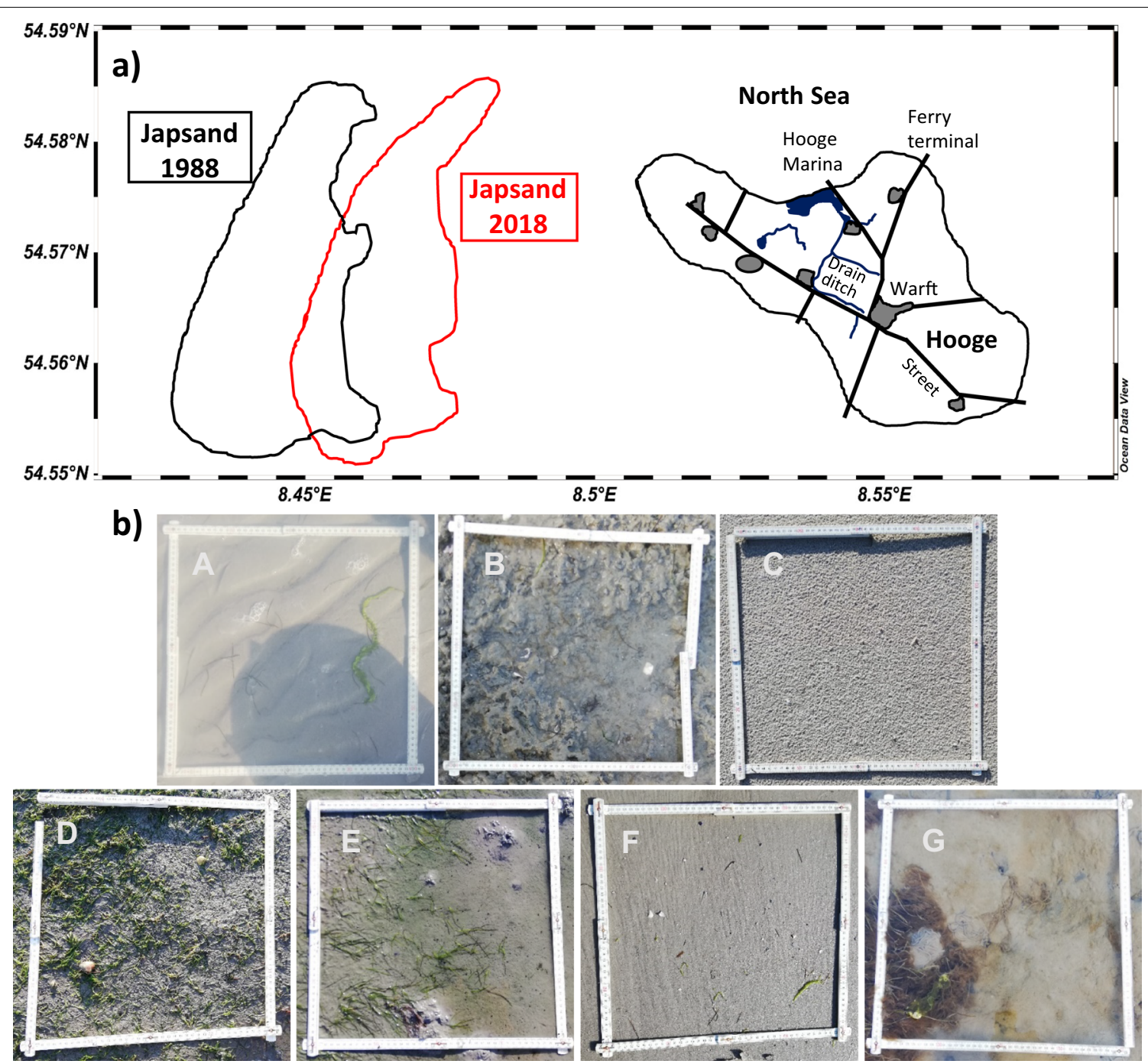

Fig. 2 Movement of the Japsand barrier sand towards Hallig Hooge. Comparison between 1988 indicated in black and 2018 indicated in red (a). The outline of the Japsand represents spring high water level. The map was drawn after the geological map from Schleswig Holstein (1:250 000, ed. $2012 \odot$ Landesvermessungsamt Schleswig-Holstein) and satellite images that were calibrated with two fix points at Hallig Hooge (coordinates: $\left.54^{\circ} 33^{\prime} 56.5^{\prime \prime} \mathrm{N}, 8^{\circ} 32^{\prime} 50.7^{\prime \prime} \mathrm{E} ; 54^{\circ} 34^{\prime} 28.8^{\prime \prime} \mathrm{N}, 8^{\circ} 31^{\prime} 02.6^{\prime \prime} \mathrm{E}\right)$. Sediment surface images from the individual sampling stations (A-G; 30.07.2019) (b)

was carefully drained off, and the uppermost $1 \mathrm{~cm}$ of the surface sediment was sliced off using a graduated plastic ring and a cutting plate [49]. Analysing the $0-1 \mathrm{~cm}$ interval was common practice in foraminiferal surveys in the Baltic and in the North Sea [e.g., 4, 50-52]. Duplicates were taken for Station A to G within a $30 \times 30 \mathrm{~cm}$ square. All samples were transferred into $100 \mathrm{~mL}$ PVC bottles (Kautex ${ }^{\circledR}$ ). Vessels filled with muddy sediments were gently slewed, bottles with sand-rich samples were cautiously tottered until the surface levelled out and could be marked on the vials immediately after sampling [49]. Within a few hours after collecting, the samples were preserved and stained with a solution of $2 \mathrm{~g}$ rose Bengal per $1 \mathrm{~L}$ ethanol (96\%, denaturised, technical quality). A preservative volume of at least $1.5 \times$ the sample volume was added [49].

Temperature and salinity of seep waters were measured with a WTW 3210 conductimeter in nearby puddles or excavated holes in the vicinity, if possible. Precision of the conductimeter was $\pm 0.5 \%$ for conductivity and $\pm 0.1{ }^{\circ} \mathrm{C}$ for temperature according to a manufacturer's test certificate. The conductimeter was calibrated using substandards of artificial seawater, which salinities were determined by using an OPTIMARE laboratory salinometer with a precision of 0.0001 permil. The accuracy of the WTW 3210 
Table 1 Geographical coordinates of sampling sites in the Japsand intertidal area, North Frisian Wadden Sea, Germany

\begin{tabular}{llll}
\hline Station & Sampling date & Latitude $\left({ }^{\circ} \mathrm{N}\right)$ & Longitude $\left({ }^{\circ} \mathrm{E}\right)$ \\
\hline $\mathrm{A}$ & 29.07 .19 & $54^{\circ} 34^{\prime} 28.3^{\prime \prime}$ & $8^{\circ} 27^{\prime} 52.0^{\prime \prime}$ \\
1 & 29.05 .19 & $54^{\circ} 34^{\prime} 28.8^{\prime \prime}$ & $8^{\circ} 27^{\prime} 54.7^{\prime \prime}$ \\
B & 29.07 .19 & $54^{\circ} 34^{\prime} 35.5^{\prime \prime}$ & $8^{\circ} 27^{\prime} 57.1^{\prime \prime}$ \\
2 & 29.05 .19 & $54^{\circ} 34^{\prime} 28.3^{\prime \prime}$ & $8^{\circ} 27^{\prime} 56.3^{\prime \prime}$ \\
F & 30.07 .19 & $54^{\circ} 35^{\prime} 08.0^{\prime \prime}$ & $8^{\circ} 28^{\prime} 58.0^{\prime \prime}$ \\
3 & 29.05 .19 & $54^{\circ} 34^{\prime} 27.5^{\prime \prime}$ & $8^{\circ} 28^{\prime} 02.2^{\prime \prime}$ \\
4 & 29.05 .19 & $54^{\circ} 34^{\prime} 23.5^{\prime \prime}$ & $8^{\circ} 28^{\prime} 16.0^{\prime \prime}$ \\
5 & 29.05 .19 & $54^{\circ} 34^{\prime} 20.7^{\prime \prime}$ & $8^{\circ} 28^{\prime} 19.4^{\prime \prime}$ \\
6 & 29.05 .19 & $54^{\circ} 34^{\prime} 18.9^{\prime \prime}$ & $8^{\circ} 28^{\prime} 22.9^{\prime \prime}$ \\
7 & 29.05 .19 & $54^{\circ} 34^{\prime} 14.9^{\prime \prime}$ & $8^{\circ} 28^{\prime} 40.2^{\prime \prime}$ \\
E & 30.07 .19 & $54^{\circ} 34^{\prime} 33.1^{\prime \prime}$ & $8^{\circ} 29^{\prime} 07.9^{\prime \prime}$ \\
C & 30.07 .19 & $54^{\circ} 34^{\prime} 06.5^{\prime \prime}$ & $8^{\circ} 29^{\prime} 10.5^{\prime \prime}$ \\
8 & 29.05 .19 & $54^{\circ} 33^{\prime} 56.2^{\prime \prime}$ & $8^{\circ} 29^{\prime} 54.7^{\prime \prime}$ \\
D & 30.07 .19 & $54^{\circ} 33^{\prime} 47.4^{\prime \prime}$ & $8^{\circ} 30^{\prime} 27.4^{\prime \prime}$ \\
G & 30.07 .19 & $54^{\circ} 33^{\prime} 56.4^{\prime \prime}$ & $8^{\circ} 30^{\prime} 58.6^{\prime \prime}$ \\
Hooge & 29.05 .19 & $54^{\circ} 34^{\prime} 11.0^{\prime \prime}$ & $8^{\circ} 31^{\prime} 16.3^{\prime \prime}$ \\
\hline
\end{tabular}

conductimeter equipped with a TetraCon 325 probe was \pm 0.13 units ( 1 -sigma value).

Foraminiferal samples were kept in the rose Bengal staining solution for at least 2 weeks at ca. $8{ }^{\circ} \mathrm{C}$ in the dark to ensure that staining of the cytoplasm of formerly living foraminifera was pervasive [53]. Afterwards, the samples were processed following the procedure described by Wefer [54], Schönfeld et al. [55] or summarized by Lübbers and Schönfeld [56]. All samples were wet sieved using stacked $2000 \mu \mathrm{m}$ and $63 \mu \mathrm{m}$ sieves in order to remove larger particles or shell debris. The size fraction $>2000 \mu \mathrm{m}$ containing fragments of mussels, crabs, snails and seaweed was dried overnight at $50{ }^{\circ} \mathrm{C}$, weighted and stored. The size fraction $63-2000 \mu \mathrm{m}$ was also dried and weighed. After sample washing, the initial volume was determined by refilling the empty PVC vessel with tap water up to the mark on the outside. The water was transferred to a graduated cylinder and the volume was measured [49].

Due to the high amount of detrital sand and the low density of foraminiferal tests, a flotation with a high density liquid was required. Sodium polytungstate (SPT) solution with a density of $2.3 \mathrm{~g} \mathrm{~cm}^{-3}$ was applied following Parent et al. [57]. According to the authors, the recovery rate of foraminiferal tests was $>95 \%$ using a SPT solution with a density of $2.3 \mathrm{~g} \mathrm{~cm}^{-3}$. The density of the fluid was checked after every use. Residues and flotates were rinsed with tap water several times after the treatment to ensure that foraminiferal test were not coated by SPT crystals or crusts after drying. Samples containing a large number of tiny clay lumps could not be treated with SPT (Stations 1, Station B and Station D). The complete residues of these samples were picked dry.

Rose Bengal stained foraminifera were recognized by a bright red or pink coloration of the cytoplasm $[49,55]$. Only well-stained specimens were picked and considered for this study. They were picked wet. After the stained individuals were sorted out, the flotates were dried at $50{ }^{\circ} \mathrm{C}$. In order to investigate the assemblage composition of non-living foraminifera, aliquots were made with a Green Geological microsplitter from one sample per station. A target number of 200-300 dead foraminiferal specimens was aimed to $[34,49]$. The split was picked for foraminiferal tests completely. If less than ca. 100 specimens were available in $1 / 2$ split, the entire floatate was picked. Living and dead foraminifera were sorted separately by species in Plummer cell slides, fixed with glue and counted. The size distribution of the three-ranked species was assessed by measuring the maximum test diameter on all intact specimens of Elphidium selseyense, E. williamsoni and Ammonia batava collected in the cell slides. The measurements were made with Leica Wild (Leica Wild M60 and M80) stereomicroscopes at 60x magnification by using an eyepiece reticle with a resolution of $12.5 \mu \mathrm{m}$.

Light microscopic images for species' documentation were taken with a Keyence VHX-700 FD digital microscope (living specimens) and a Keyence digital microscope VHX.7000 at the Institute of Geosciences, Kiel University. Statistical analysis of the census data, e.g., calculation of diversity indices, were performed with Past $4.0[58]$.

\section{Results \\ Hydrography}

On-site measurements of temperatures and salinities at low tide and comparison with those recorded by the adjacent MARNET monitoring network stations are important to assess the diurnal, intertidal variability of these environmental parameters. The surface temperature varied from $19.4{ }^{\circ} \mathrm{C}$ at Station 8 and $22.8{ }^{\circ} \mathrm{C}$ at Station 3 in May 2019 (Additional file 1: Table S1). The mean temperature was $21.3( \pm 1.4){ }^{\circ} \mathrm{C}$. The mean salinity was $34.0( \pm 4.5)$ and varied between 40.4 at Station 8 and 30.3 at Station 1 . Temperatures in July ranged from $21.1{ }^{\circ} \mathrm{C}$ at Station A to $26.3{ }^{\circ} \mathrm{C}$ at Station E (Additional file 1: Table S1). The mean temperature was $23.9( \pm 2.7){ }^{\circ} \mathrm{C}$. The mean salinity in July was $34.8( \pm 1.7)$. The maximum salinity was 38.1 at Station E and the minimum salinity of 31.6 was measured at Station F. Overall, no pronounced trend in salinity or temperature was recognised along the transect. 
The temperature and salinity measurements on seep waters or in little puddles were strongly influenced by evaporation and heating by the atmosphere and solar radiation during emergence at low tide. Near-surface water data from Station Hörnum of the MARNET monitoring network recorded water temperatures of $11^{\circ} \mathrm{C}$ in May and $18{ }^{\circ} \mathrm{C}$ in July 2019 on average, i.e. lower by about $10 \mathrm{~K}$ in May and $3 \mathrm{~K}$ in July as compared to measurements for the present study on Japsand. Station Deutsche Bucht recorded salinities between 31.4 and 32.9 PSU in May, and between 32.7 to 33.1 PSU in July 2019. The averages of both ranges were about 2 units lower than the measurements on Japsand (https://www.bsh.de/DE/ DATEN/Meeresumweltmessnetz/Jahreszeitreihen/jahre szeitreihen_node.html).

\section{Sedimentology}

Five stations (1-3, A, B) and Station F in the North were located on the seaward, western part of the Japsand. This area is mainly influenced by waves from the open North Sea. Two different surface sediments were recognised, sand and silty clay (Fig. 2b).

Stations 1 and B were the westernmost station closest to the average low tide level. An extremely slippery and stiff silty clay prevailed. Diatom mats and bivalve shells were recorded. The surface was extremely uneven and intersected by numerous erosional ditches. The sediment was most likely a glacial till or Eemian clay, which was exposed to the high wave energy at the seaward side (Fig. 2b).

Station 2, A and F showed a completely different sedimentological inventory. The surface sediment was a pure sand, wave ripple marks were common (Fig. 2b). The area characterizes the beach face and swash zone, particularly at low tide.

Station 3 was located at the highest part, above mean water level, at a berm crest built of bivalve shells. The sediment was sand, diatom mats were common and the surface of the sediment was perforated by aeration holes (Fig. 2b).

The area between Station 4 and Station 8, including Station 5, 6, 7 and $C$, was situated at the eastern, landward side of the Japsand. The sediment was predominately sand and drier than at Stations 2 and 3. Nevertheless, the area was frequently flooded, which reflected in the presence of bivalves and gastropods. Especially the surface of Station 7 was covered with ventilation holes for snails and other animals. The colour of the sediment surface was slightly brownish to black. Station E was located at the northeastern part of Japsand in an embayment with calm conditions and represented a mixed mud flat. The sediment was a silty sand and contained shells and fragments of bivalves and gastropods. Crabs and lugworms were common. Furthermore, the sediment showed a marked shift in colour from brown to grey at a few $\mathrm{mm}$ depth. Station 8 represented the transition between sand flats and mixed flats. The sediment was a silty sand in the uppermost $\mathrm{cm}$, whereas the silt content increased and the colour darkened with depth. Hydrobia and their corresponding ventilation holes were recognised in large numbers.

Stations D and G were located on the mud flat near Hallig Hooge. Brown algae, seaweed, diatom mats, lugworm excrements as well as bivalves and gastropodes were recorded (Fig. 2b). Below $0.5 \mathrm{~cm}$, the mud was anoxic as depicted by a shift of the sediment colour to darker tones.

Station Hooge was close to the jetty of "Volkerswarft". The sediment was a stiff and consolidated silty sand (Fig. 2b).

\section{Living foraminiferal faunas}

The living foraminiferal faunas from Japsand comprised 10 different species, of which two were agglutinated (Eggerelloides scaber and Saccammina sp.) (Fig. 3, Additional file 1: Table S1). Eight species were calcareous and belong to the genera Ammonia, Elphidium and Haynesina. Ammonia batava, Elphidium selseyense and Elphidium williamsoni were the three most common species with average proportions of $57 \%, 22 \%$ and $16 \%$, respectively. Individual proportions at the different stations ranged between 15 and 100\% for Ammonia batava, 8 and 100\% for Elphidium selseyense and 2 to $100 \%$ for Elphidium williamsoni (Fig. 4). Elphidium oceanense, Elphidium gerthi and Haynesina depressula were rare.

At three of 16 stations, i.e. Hooge, 8 and 4, no living foraminifera could be recovered. The foraminiferal population density hence varied between 0 and 246 individuals per $10 \mathrm{~cm}^{3}$ (Fig. 4). The highest standing stock values were recorded at the outer part of Japsand. The population densities were very low or samples were barren between the luv side and the end of the lee side of Japsand. From the end of Japsand at the landward side up to Hallig Hooge, the foraminiferal population densities increased again. The Fisher's alpha diversity index was generally very low and did not exceed 2.0 (Additional file 1: Table S1). Surprisingly, the index displayed a distribution pattern matching the foraminiferal population density distribution. This is most likely due to the low population densities in that only the most frequent species were captured at the given sample size.

Among the individual species, Ammonia batava was common at the seaward side of the Japsand (Station A-Station 2) and re-appeared at two stations close to Hallig Hooge (Station D, G). Elphidium selseyense showed a similar distribution pattern though this species was 

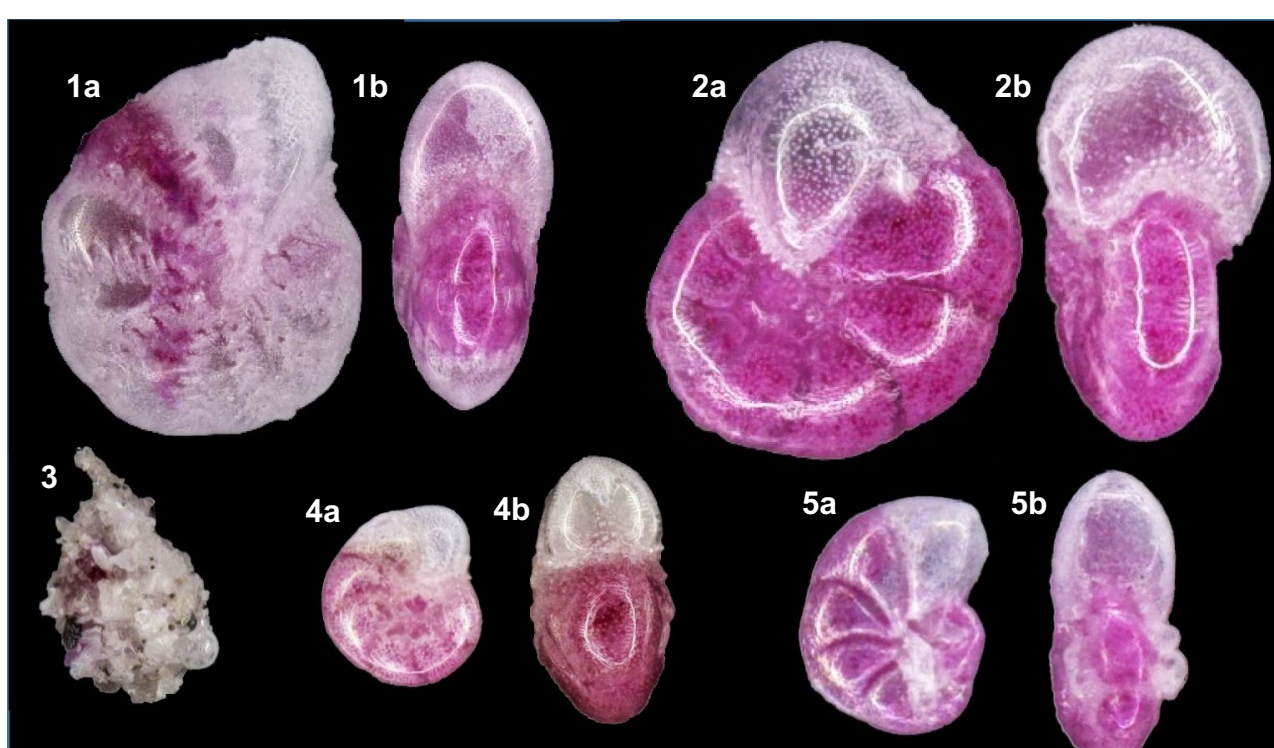

$5 \mathbf{b}$
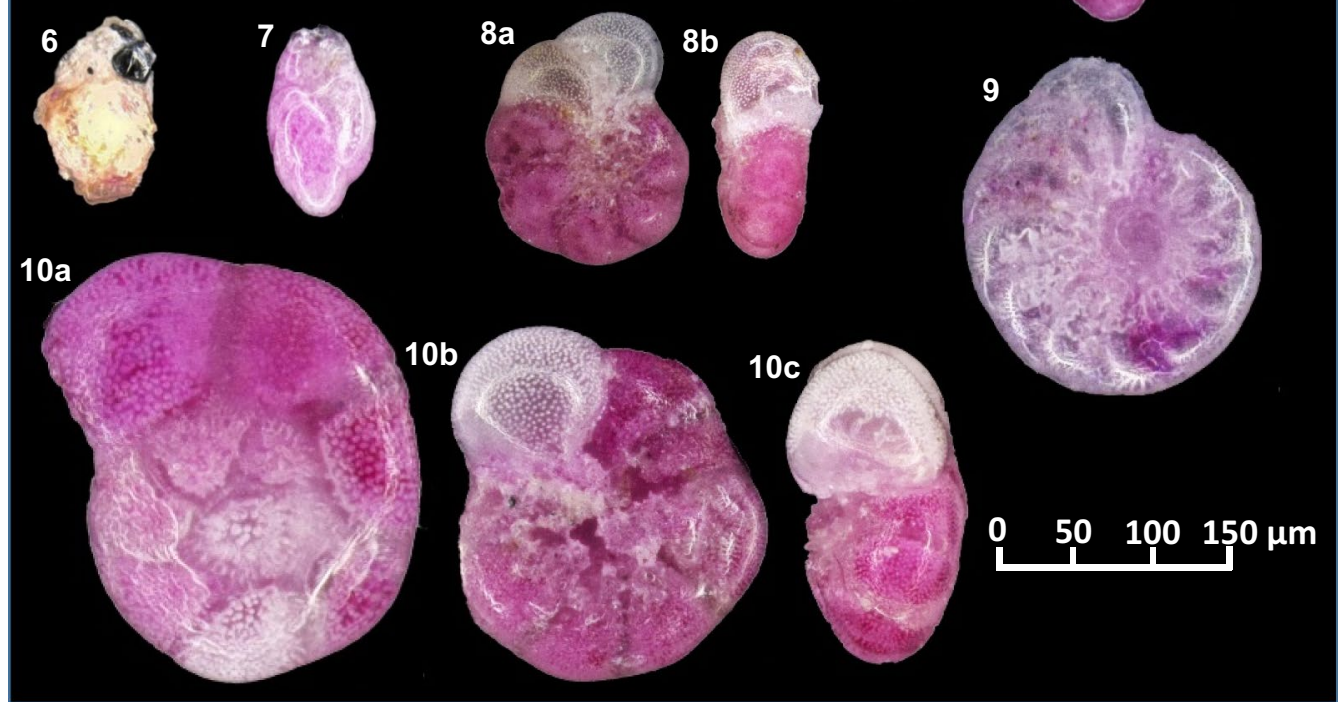

Fig. 3 Live rose Bengal stained foraminifera from the Japsand area, North Frisian Wadden Sea, Schleswig-Holstein, Germany. 1: Elphidium williamsoni (St. C) 1a: lateral view, 1b: side view. 2: Haynesina germanica (St. D), 2a: lateral view, 2b: side view. 3: Saccamina sp. (St. 2). 4: Elphidium oceanense (St. D), 4a: lateral view, 4b: side view. 5: Haynesina depressula (St. 2), 5a: lateral view, 5b: side view. 6: Eggerelloides scaber (St. 2). 7:

Bulliminella elegantissima (St. D). 8: Elphidium selseyense (St. D), 8a: lateral view, 8b: side view. 9: Elphidium gerthi (St. 5). 10: Ammonia batava (St. D), 10a: spiral side, 10b: umbilical side, 10c: side view. The locations of the individual stations are indicated on Fig. 1b

additionally present at the landward extension of Japsand (Station 5, 6 and E) and at Station F in the northernmost part. Elphidium williamsoni showed a trend almost opposite to Ammonia batava and was found in substantial numbers at two stations only (Station 7 and C), which were located on the landward side of Japsand. Haynesina germanica sporadically occurred at stations where muddy fine sand or mud prevailed, and it was more common at the landward Stations D and G (Fig. 4).

Duplicate samples were taken at Stations A-G and analysed separately. The statistical significance of the similarity of the faunal composition of the duplicates was investigated with a non-parametric Wilcoxon Mann-Whitney test using the program PAST [58]. The $\mathrm{p}$-values were all $>0.05$ (alpha $=5 \%)$, indicating that the species proportions from the duplicates were not significantly different with a $95 \%$ confidence level. The only exception was Station E with a p-value of 0.04, which demonstrated that the population of the two replicates at this station were significantly different from each other. 


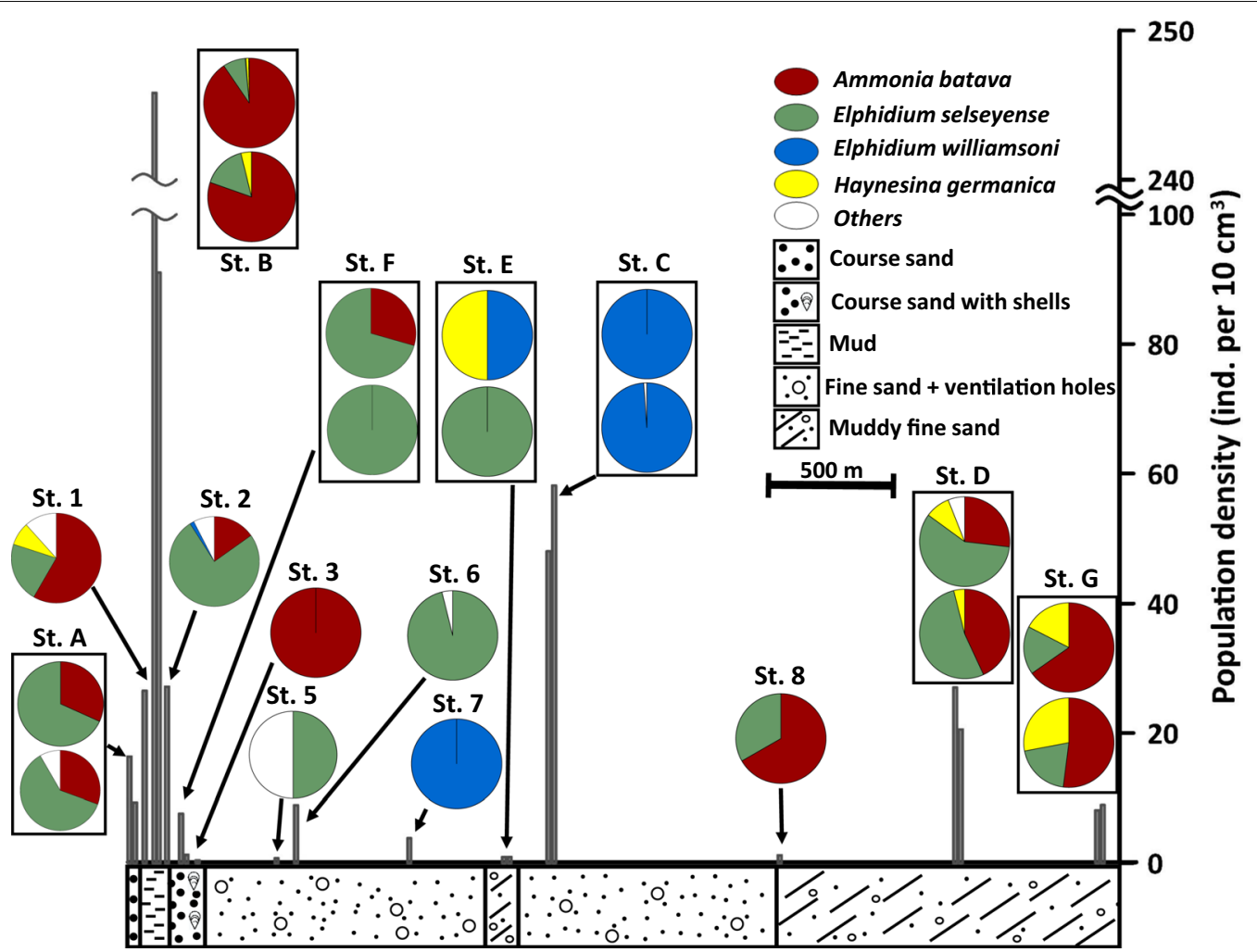

Fig. 4 Population density (individuals per $10 \mathrm{~cm}^{3}$ ) of living rose Bengal stained foraminifera and sediment type from the Japsand area, North Frisian Wadden Sea, Germany. Pie charts show the proportion of individual species on the living fauna. Pie charts grouped within a rectangle represent duplicates at the same station where the upper pie chart represents sample 1 and the lower pie chart represents sample 2. Please note that the vertical axis is clipped and the horizontal axis is spread for the westernmost samples (St. A, 1, B and 2) for better visualization

\section{Dead foraminiferal assemblage}

The living fauna as described above represents only a snapshot in time, i.e. our sampling during summer. The dead foraminiferal assemblage is considered a perennial product of multiple generations, augmented by recent reproduction events and moulded by reworking and dissolution. In particular, the dead foraminiferal assemblages at Japsand comprised 26 different species of which 23 species were calcareous whereas only 3 species were agglutinating. Elphidium represented the most diverse genus with 9 different species (Fig. 5, Additional file 2: Table S2). The most abundant species were Ammonia batava (24\%), Haynesina germanica (22.5\%), Elphidium selseyense (13.8\%) and Elphidium waddense (13\%) (Fig. 6). These species were found in every sample. Elphidium williamsoni (9.2\%) was only the fifth ranked species. In single samples, E. williamsoni represented more than $50 \%$ of the assemblage (Station 7, Station C, smp. 1).

The abundances of empty tests were highest at the seaward side of Japsand with a maximum of 2079 tests per $10 \mathrm{~cm}^{3}$ at Station 2 (Fig. 6). The test density strongly declined eastwards up to a minimum of 6 test per $10 \mathrm{~cm}^{3}$ at the landward side of the barrier sand. Similar low values showed up at Station Hooge (12 empty tests per $10 \mathrm{~cm}^{3}$ ) (Fig. 6).

The Fisher's alpha diversity index was with 4.94 highest at Station Hooge and lowest (2.22) at Station 1. The highest species richness was recorded at Station D, where 19 different species were found (Additional file 2: Table S2).

\section{Size distribution}

Biometric measurements were performed to assess the growth state of the populations, and to identify cohorts of juveniles as indicator of recent reproduction events. The most abundant species of the living fauna, i.e. $E$. selseyense, E. williamsoni and A. batava were measured considering both, living fauna (Figs. 7, 8, Additional file 3: Table S3) and dead assemblage (Figs. 7, 8, Additional file 4: Table S4). The size distributions in terms of maximum test diameter of living Elphidium selseyense were quite uniform in the individual samples. According to the Wilcoxon Mann-Whitney test, the populations in duplicate samples were not significantly different with the exception of Station A. The size distributions of the dead assemblages were uniform as well (Fig. 7). 


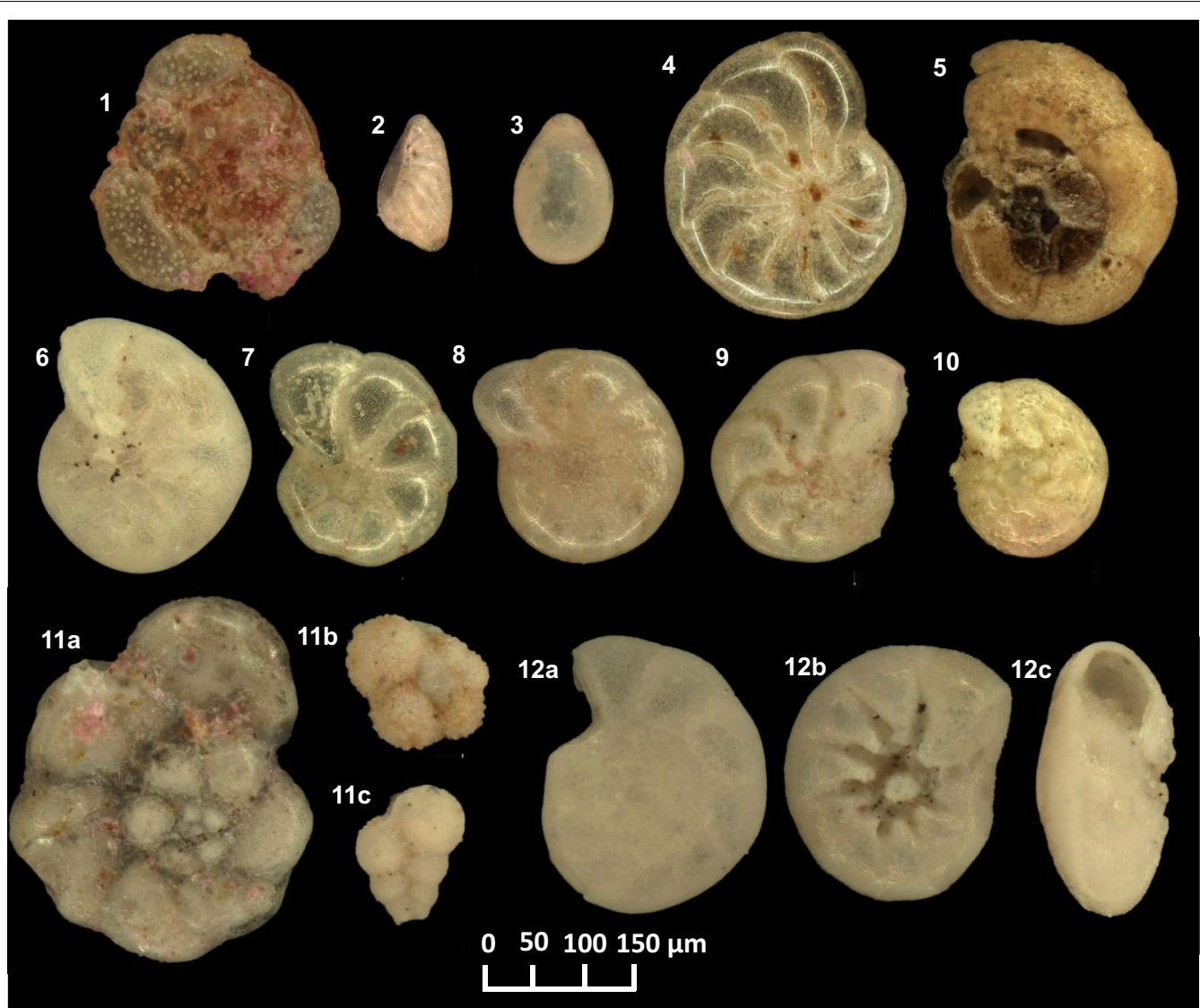

Fig. 5 Selected foraminiferal species from the dead foraminiferal assemblage from the Japsand area, North Frisian Wadden Sea, SchleswigHolstein, Germany. 1: Planorbulina mediterranensis (St. 6). 2: Nonionella crassesuturalis (St. B). 3: Fissurina lucida (St. B). 4: Elphidium voorthuyseni (St. D). 5: Trochamina inflata (St. 2). 6: Elphidium incertum (St. 8). 7: Haynesina orbicularis (St. 2). 8: Elphidium waddense (St. 8). 9: Elphidium clavatum (St. D). 10: Elphidium oceanensis (St. D). 11: reworked foraminifera from the Cretaceous, 11 a: Praeglobotruncana sp. (St. 6), 11 b: Hedbergella sp. (St. D), 11 c: Heterohelix sp. (St. D). 12: Ammonia aberdoveyensis (St. 2), 12a: spiral side, 12b: umbilical side, 12c: side view. The locations of the individual stations are indicated on Fig. $1 \mathrm{~b}$

Elphidium williamsoni yielded a sufficient number of specimens only in three samples. The individual mean value of these samples was in the range of upper and lower quartile of the other samples (Fig. 7). The size distribution of Station $\mathrm{C}$ duplicates were almost identical.

Living Ammonia batava showed a large scatter in the size distributions of individual samples. Wilcoxon MannWhitney test revealed that the populations of duplicate samples of station $A$ and $C$ were not significantly different, while Station $B$ and $G$ show significant differences (St. B: $p=0.004$, St. G: $p=0.03$ ). The size distribution of the dead assemblages showed a large scatter among individual samples as well (Fig. 7).

Once the biometric data from all samples were merged, Elphidium selseyense showed an asymmetric distribution in the living fauna, which appeared as a left skewed rather than log-normal distribution (Fig. 7). The size distribution of the entire dead assemblage was almost symmetrical. The mean value was $271 \pm 54 \mu \mathrm{m}$ and thus substantially higher than in the living fauna $(180 \pm 54 \mu \mathrm{m})$ (Fig. 8).

Elphidium williamsoni showed a symmetrical size distribution histogram in the combined living fauna with a mean value of $264 \pm 115 \mu \mathrm{m}$. In the dead assemblages, $E$. williamsoni showed much more scatter around a mean of $289 \pm 80 \mu \mathrm{m}$ (Fig. 8). It has to be noted however, that the dead specimens from samples taken in July (Stations A through D), were consistently smaller.

The histogram of the entire Ammonia batava population showed a log-normal distribution pattern with a high number of small individuals and a low number of large specimens. The mean value was $165 \pm 65 \mu \mathrm{m}$. The size distribution of the entire dead assemblage showed a mean of $274 \pm 66 \mu \mathrm{m}$. The distribution was almost symmetrical and closely resembled a Gaussian curve (Fig. 8).

The cumulative size distribution of Ammonia batava and Elphidium selseyense were plotted on a log-probability scale (Fig. 9). The data pattern revealed that the living 


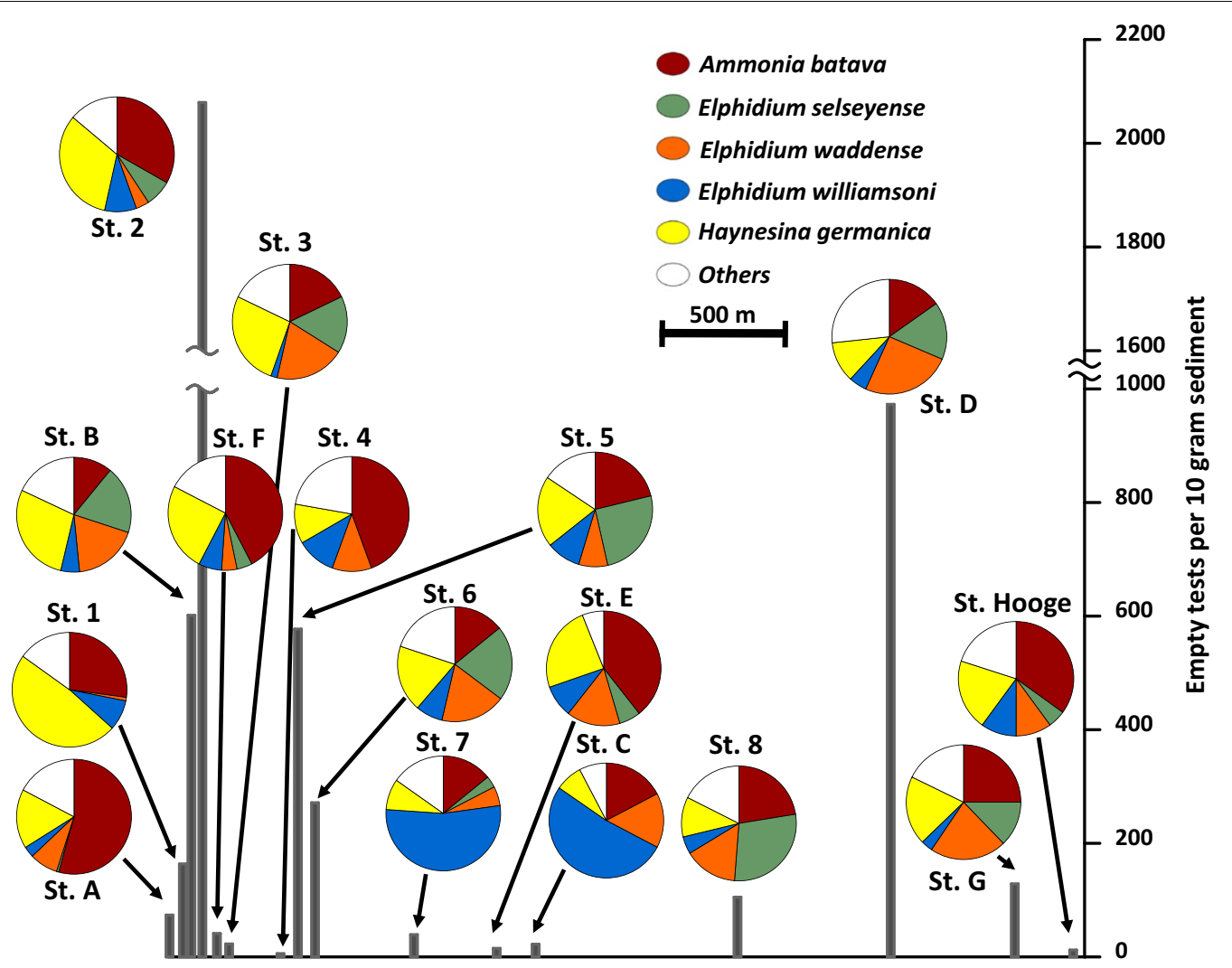

Fig. 6 Empty tests per $10 \mathrm{~g}$ sediment of dead foraminifera from the Japsand area, North Frisian Wadden Sea, Germany. Pie charts show the proportion of individual species on the dead assemblage. Please note that the vertical axis is clipped and the horizontal axis is spread for the westernmost samples (St. A, 1, B and 2) for better visualization

assemblage of both species was composed of two different subpopulations, each having an individual log-normal distribution that was displayed by a straight line (Fig. 9). The subpopulation of small specimens ranged from 80 to $120 \mu \mathrm{m}$ test diameter in E. selseyense and $80-100 \mu \mathrm{m}$ in A. batava.

\section{Discussion}

\section{Reproductive state of the foraminiferal faunas}

Reproductive events in intertidal or near-shore foraminifera may take place several times during the year $[21,54$, 59], mainly depending on or triggered by the availability of fresh food [60, 61]. Even a continuous reproduction throughout the year has been suggested, though with lower rates during winter [62]. The biometric data of the present study were therefore explored to assess whether reproduction has recently taken place and how this may have influenced the assemblage composition.

The size distribution of living Ammonia batava and Elphidium selseyense revealed two different subpopulations, of which the subpopulation of small specimens comprise 18 and $15 \%$ of the whole population only. If such small specimens were holding the majority of all living individuals, this may indicate the onset of the reproductive season, which mainly takes place in the summer months [e.g., 65]. During asexual reproduction, one single foraminifer may produce offspring of more than 100 very small juveniles [e.g., 6, 66]. It is evident that such a scaled phenomenon can strongly influence the living assemblage. Elphidium williamsoni, on the other hand, showed a straight line on log-probability plot (Fig. 9) indicating that only a single population was present. Reproduction might not have been started, the juveniles were too small to be captured by a $63-\mu \mathrm{m}$ mesh, or they could have been displaced by currents or tides. At Station C, sample 1, however, the dead assemblage of E. williamsoni showed 23 well-preserved specimens very uniform in size, which contained spratty, unstructured remnants of cytoplasm. The sample has been taken in July. This observation corroborated the assumption that reproduction of E. williamsoni was just commencing. The mean diameter of living E. williamsoni was with ca. $263 \pm 51 \mu \mathrm{m}$ slightly lower than $289 \pm 80 \mu \mathrm{m}$ in the dead assemblage. The mean diameter of dead specimens 


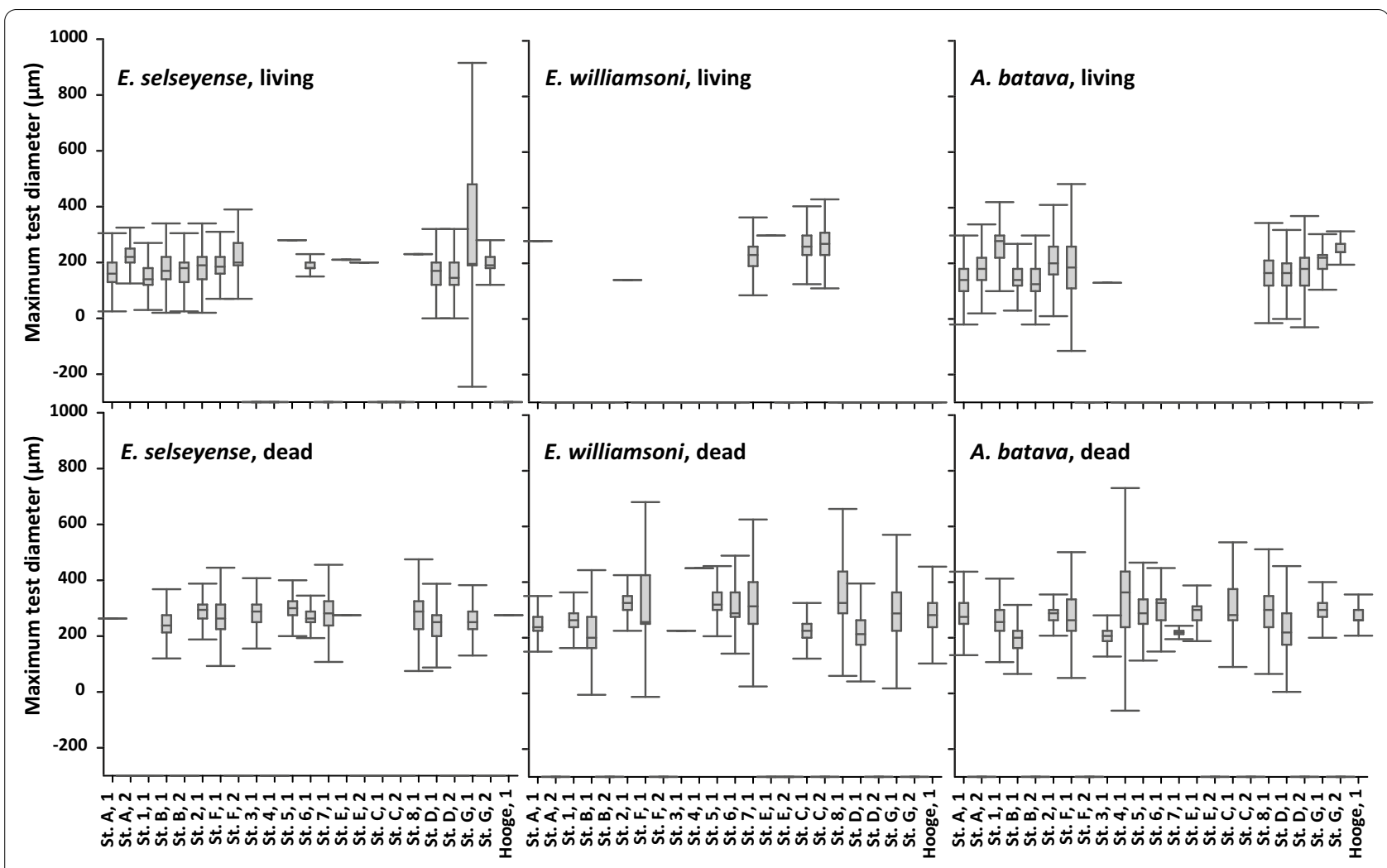

Fig. 7 Ranges of maximum test diameter of the most important foraminiferal species from the Japsand area, North Frisian Wadden Sea, Germany. Top: living rose Bengal stained foraminifera and bottom: dead foraminifera. The vertical bar in the middle of the box represents the median, the box edges are the first and third quartil (also upper and lower quartil) and the whiskers represent $1.5^{*}$ IQR (Interquartil range $=$ difference between lower and upper quartil)

displays the average size of the individuals when reproduction usually takes place. As such, the size difference of living and dead specimens indicates that the specimens would have to grow for some more time before reproduction maturity is reached. None-the-less, our sampling represents only two surveys in almost 9 weeks and at least bi-weekly sampling is required to constrain the timing of reproductive events $[62,67]$.

\section{Comparison of living and dead assemblages}

The dead foraminiferal assemblage showed a species richness of 26 that was more than twice as high as the 10 species recorded in the living fauna. Furthermore, the foraminiferal test abundance of the dead assemblages exceed the abundance of living specimens by one order of magnitude, which is a common feature and often reported in the literature [e.g., 39, 68]. General patterns of abundance were uniform at the seaward side of Japsand in dead assemblages and living faunas up to Station 3 . This similarity was changing on the landward side of Japsand. Especially at Stations 5 and 6, the dead assemblage showed much higher abundances and species richness values. This was also mirrored in the Fisher's alpha index, which was close to the maximum of all diversity index values in the dead assemblage and only slightly above the minimum of all index values in the living fauna (Additional file 1: Table S1, Additional file 2: Table S2).

Ammonia batava was the most abundant species in the living fauna and dead assemblage, even though its dominance was less pronounced. Haynesina germanica on the other hand, which was the second ranked species in the dead assemblage, was with a relative abundance of ca. $3 \%$ on average comparatively rare in the living fauna. Elphidium selseyense was more common in the living fauna. Elphidium williamsoni was replaced by Elphidium waddense in the dead assemblage (13\%) though still abundant. Several species were found in the dead assemblage and not found in the living fauna at Japsand.

Single specimens of Fussurina lucida were found in the dead assemblages of samples Station 1, B and 8. This stenohaline species was common in near shore and shelf environments in NW Europe [69, 70] and was scarcely recorded in intertidal environments of the North Sea [71]. Planorbulina mediterranensis was also found occasionally as single specimens. The species was preferentially living attached to plants or hard substrates in 

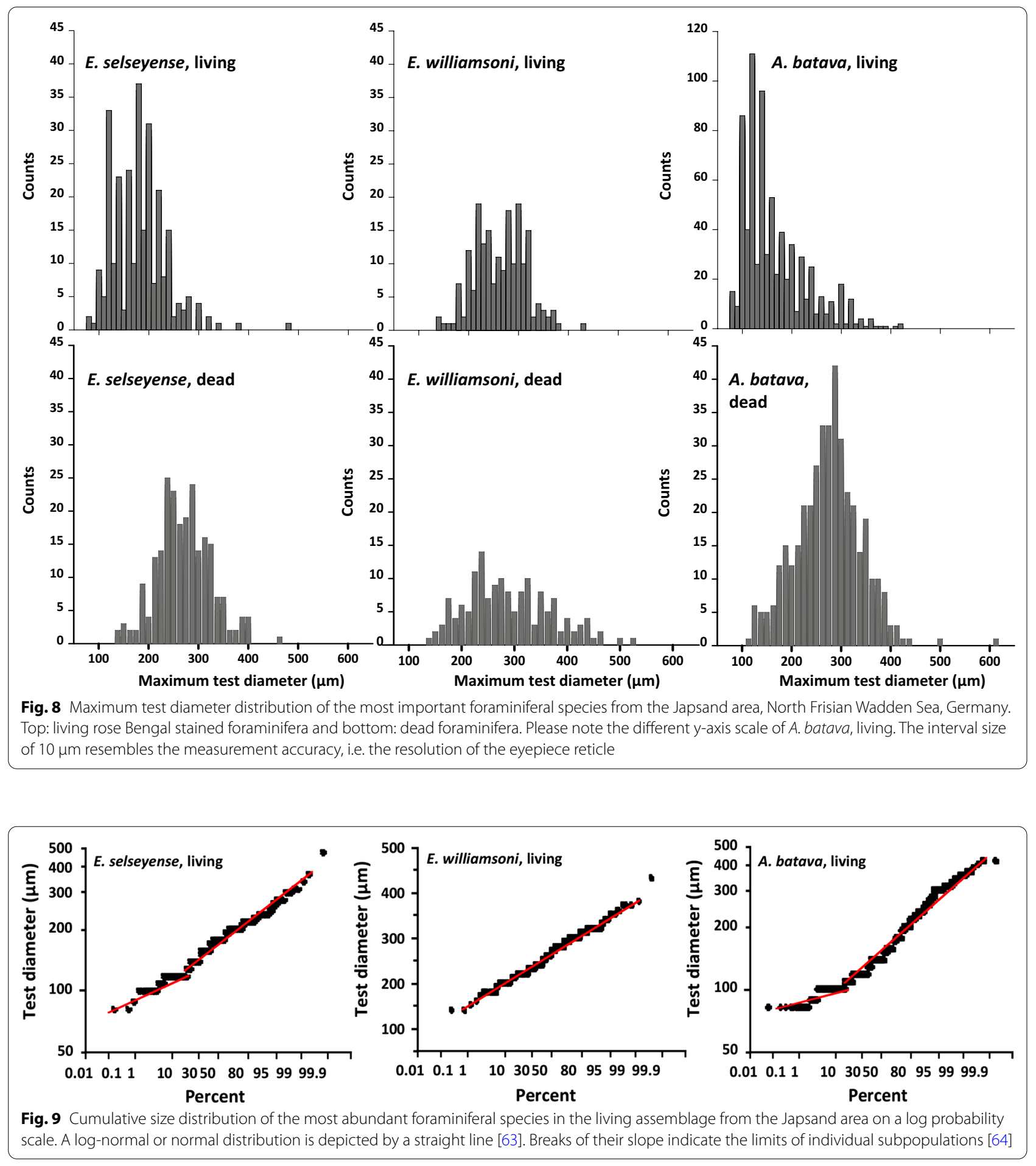

subtidal waters or turbulent shelf environments [e.g., 72-74]. The agglutinating species Jadammina macrescens and Trochammina inflata were recorded as one or two specimens in some samples. They were generally associated with salt marsh plants $[5,6,75]$. The
Japsand area neither exhibited salt marshes nor deeper shelf environments. Therefore, these species must have been introduced into the system via different pathways. The landward side of the Japsand was submerged during high water and storm floods, and ebb currents may 
have transported foraminiferal tests from other parts of the North Sea to the Japsand area [e.g., 76]. These tests accumulated in sheltered areas, as the landward side of the Japsand [77, 78].

At the Stations 8 and D, Cibicides lobatus was present in the dead assemblage. This species was living in open marine areas attached to plants, seaweed and hard substrates [79]. Therefore, it was common in high-energy environments [80-82]. In the western Baltic Sea, small populations attached to red algae were reported [83]. Alve and Murray [75] suggested that small populations could enter more sheltered environments with adequate substrates and sufficient food supply. Therefore, it is conceivable that this species has been displaced to the Japsand area via currents. It is also possible that some individuals could recruit because the area is characterized by seaweed and shell fragments, which are adequate substrate for living Cibicicides lobatulus.

Bucella frigida was recorded at Stations 5, 6 and D. The species is known from water depth $>15 \mathrm{~m}$ and colder environments [84], also from Eemian deposits [85-87]. Ammonia aberdoveyensis was common in the dead assemblage. This species is associated with warmer temperatures and higher salinities [88]. Many shells of this species found in the dead assemblages of the Japsand had a dull, whitish surface and the last chamber was often missing. This points to an alteration process the shells underwent during fossilisation, which in turn may be seen as an evidence for reworking from older sediments and redeposition, which lead to the influx of fossil foraminifera into the dead assemblage. This also applies to Cretaceous foraminifera that were reworked from Pleistocene glacial till, in which they have been incorporated when glaciers eroded Chalk bedrock [59, 89].

\section{Connectivity of the foraminiferal faunas}

Langer et al. [90] and Haake [71] proposed conceptual models for the horizontal distribution of foraminiferal species along a transect from the shoreline to the open sea, or from mud flats to sand flats. According to these models, Haynesina germanica and Elphidium selseyense were distributed nearly equally in all facies. Elphidium williamsoni was common on the mixed flats. Ammonia batava was restricted to sand flats according to Langer et al. [90], while Haake [71] found it more common on mud flats but not restricted to this environment. These models do only partly apply to the Japsand area. Elphidium williamsoni was found to be confined to the mixed flats (Fig. 4). Furthermore, Elphidium selseyense was common in all facies. Ammonia batava was frequent on the sand flats, common on the mud flat but almost absent on the mixed flat, which is in agreement with Haake [71] and Langer et al. [90]. Contrary to the conceptual models,
Haynesina germanica was rare on the mixed flats and constituted only a small proportion of the fauna (Fig. 4).

Due to the permanent redeposition of intertidal sands and the ubiquitous lateral displacement of foraminiferal tests, as explained above, it is necessary to assess the connectivity between different foraminiferal faunas in a wider geographical range. Helgoland inner port represents a first stage from the open sea to a more sheltered environment. The fauna showed several foraminiferal species that were normally found at greater depths around the island (e.g., Hopkinsina pacifica). The dominant species was Elphidium selseyense (58\%). Ammonia batava, Ammonia tepida and Haynesina germanica were rare (Fig. 10, Additional file 5: Table S5). Agglutinating littoral species were not found. A connectivity between Helgoland and Japsand was clearly visible in the presence of Elphidium selseyense, Ammonia batava and Haynesina germanica even though proportions of the species were shifting towards a dominance of Ammonia batava (57.1\%) on the expense of Elphidium selseyense (22\%) (Fig. 10). Deep water species were not present anymore, but agglutinating species were in minority, which was due to the sandy environment and the strong hydrodynamics at Japsand [78]. Furthermore, Elphidium williamsoni appeared, which marked a first connection to the higher, intertidal environments.

The next step on the way from the open North Sea to the mainland is the Bay of Tümlau, near Westerhever [4]. The most common species in samples with a sand

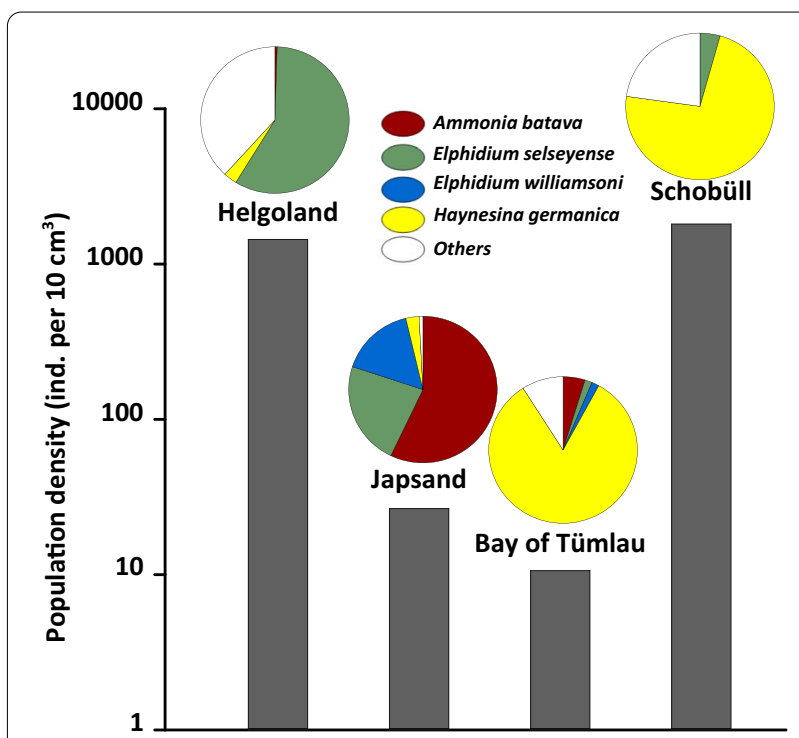

Fig. 10 Population density (individuals per $10 \mathrm{~cm}^{3}$ ) of living rose Bengal stained foraminifera from the Japsand area, North Frisian Wadden Sea, Germany and comparative locations at Helgoland, the Bay of Tümlau [based on 4] and Schobüll. Pie charts show the proportion of individual species in the living fauna 
content of more than 40\% (see Additional file 6: Table S6) from this area was Haynesina germanica (90.2\%). Ammonia batava, Elphidium selseyense (Elphidium excavatum in [4]) and Elphidium williamsoni were present with much lower proportions. This fauna was linking not only to Japsand but also to the tidal flats at Schobüll (Fig. 10, Additional file 7: Table S7).

The marginal mudflats before the indigenous saltmarsh at Schobüll depicted that the connection between the different environments can be tracked further. The connecting species were Haynesina germanica (73\%) and Elphidium selseyense (4\%) (Fig. 10). Ammonia batava was replaced by Ammonia tepida (17\%), and Elphidium williamsoni disappeared, though it was occasionally found in the salt marsh here [6].

\section{Conclusions}

Ammonia batava was the most abundant species in the living fauna and dead assemblage at Japsand. Elphidium selseyense was more common in the living fauna. Haynesina germanica was rare in the living fauna but frequent in the dead assemblage. Elphidium williamsoni was common in the living fauna but rare in the dead assemblage. Elphidium waddense was only found in the dead assemblage. It is conceivable that the high proportions of living Ammonia batava and Elphidium selseyense were effected by reproduction. The size distribution curves of both species indeed provided corroborating evidence that reproduction had recently taken place, whereas reproduction of Elphidium williamsoni had probably just started (Figs. 7 and 8).

Several species were found in the dead assemblage and not found in the living fauna. Those species have been reported from other areas of the North Sea and North Atlantic. As they were comparatively rare, they were probably displaced to the Japsand area via tidal currents. Recent distribution and preservation of Bucella frigida and Ammonia aberdoveyensis revealed their reworking from older sediments. Therefore, fossil foraminifera could have a certain influence on the structure of the dead assemblage. An ubiquitous lateral displacement of foraminiferal tests at short distance certainly prevailed on Japsand, as evidenced by the uniform assemblage composition of the dead assemblages, and the same size distribution of empty tests of different species.

The conceptual model of Haake [71] and Langer et al. [90] on the distribution of sublitoral foraminifera was confirmed in the present study, with the exception of Elphidium williamsoni. It is a matter of further investigations whether this may be due to the specific ecological requirements of this species, as it holds and sequesters chloroplasts [91, 92].
A connection between the open North Sea environment and the mainland can be tracked in the living fauna of benthic foraminifera (Fig. 10). Species depicting this link at most were Haynesina germanica, Ammonia batava and different Elphidium species. They are known to have a wide range of distribution and also an excellent ability of adapting to different environments [93-95] thus, they can be classified as opportunistic species. While major vectors for the transoceanic transport of foraminifera were ships' ballast water [96-98] or the digestive pathway of fish $[99,100]$, the proliferation of foraminifera and their propagules in intraoceanic settings like the North Sea was mainly effected by suspended load via currents and tides [76, 101]. Our results indicated that the latter of the before mentioned processes were dominant environmental factors shaping in particular the dead foraminiferal assemblages in the Japsand area.

\section{Appendix 1. Foraminiferal reference list and taxonomic notes}

Taxonomy of benthic foraminifera identified in this study. Genera and species are listed in alphabetical order. The type references were retrieved from the Ellis and Messina [102] catalogue. Emphasis was given to publications on North Sea foraminifera for species determination. Papers on genetic-morphological investigations of Ammonia and Elphidium species were also considered. If possible, at least one reference to a high-quality image in a recent publication is provided for each species.

Ammonia aberdoveyensis Haynes 1973 [103], p. 184, fig. 38, nos. 1-7, pl. 18, fig. 15. "Ammonia beccarii var. aberdoveyensis" [104], p. 56, fig. 18., nos. A-C. Horton and Edwards [5], p. 70, pl. 3, figs. 10a-c. "Ammonia sp. T2" Bird et al. [88], p. 19, fig. 2., nos. CK02, CK28, CK69, LK74. Note: most specimens are dull and corroded, and the last chamber is often missing. The spiral side of the biconvex test is shallow conical, the sutures are oblique and slightly raised. The straight sutures on the umbilical side show narrow incisions close to the umbilicus where the chamber extensions are raised and thickened. A small umbilical knob is present in many specimens giving the umbilical area a stellate appearance. Our specimens from Japsand are very similar to the T2b cryptic species of [88], while this genotype has not been recorded in the North Sea to date. The umbilical area of our specimens is similar to Ammonia catesbyana [105] reported from the southern North Sea by Langer et al. [90], even though the spiral side of the latter is rather flat than conical, and their outline is lobate rather than as smooth as in $A$. aberdoveyensis.

Ammonia batava (Hofker)=Streblus batavus Hofker 1951 [106], p. 498, figs. 335, 340, 341. "Streblus batavus" 
Haake [71], p. 52, pl. 6, figs. 6-12. Langer et al. [90], p. 90, pl. 1, figs. 8-13. Schönfeld et al. [55], fig. 2a, pl. 1, figs. 1-3, 14-17, 31-34. Müller-Navarra et al. [4], p. 74 , fig. 3 , nos. 15,16 . Note: the species is common in the North Sea. Their test is compressed biconvex. The last chambers are inflated in adult specimens and may be separated by a fissure from the penultimate whorl where the sutures are raised on the spiral side. A distinct umbilical knob is surrounded by thickened and pointed chamber extensions, which is a diagnostic character of this species. The genotype T3S has been assigned to $A$. batava by Bird et al. [88] .

Ammonia tepida (Cushman)= Rotalia beccarii var. tepida Cushman 1926 [107], p. 79, pl. 1. Hayward et al. [108] p. 353, pl. 1, figs. 1-8. Hayward et al. [109], p. 264, pl. 2-4, fig. T. "Ammonia beccarii" Polovodova et al. [50], p. 141, pl. 1, figs. 1-4. "Phylotype T6" Richirt et al. [110], fig. 7, no. Ai052. Note: the specimens from Japsand show morphological features of both, T1 and T6 genotypes, in particular raised or flush sutures, a narrow or wide umbilicus. These features are not developed in a consistent manner in that a secure distinction between both varieties would be possible. Therefore, the species name Ammonia aomoriensis [111], which has been used for T6 [112], cannot be applied here [88]. The pore size is, however, diagnostic for a morphological distinction of $\mathrm{T} 1$ and $\mathrm{T} 6$ genotypes [110], p. 85]. This feature cannot be resolved by light microscopy, and not every specimen can be examined under the SEM. As the Japsand specimens are morphologically in reasonable good agreement with A. tepida locotypes, we keep with this more generally used species name [e.g., 113, p. 295].

Ammoscalaria runiana (Heron-Allen and Earland $=$ Haplophragmium runiana Heron-Allen and Earland 1916 [114], p. 224, pl. 40, figs. 15-18. Kripner [115], p. 21, pl. 2, figs. 1-15. Lutze [52], p. 91, pl. 11, figs. 1-18, pl. 15, figs. 18-20. Murray and Alve [116], p. 25, fig. 15, nos. 2-5. Nordberg et al. [12], pl. 1, fig. j. Note: the chambers are rather indistinct and they rapidly increase in diameter, leaving the central area depressed. A detachment of the last chambers was only observed in one specimen from Japsand.

Bolivina earlandi Parr 1950 [117], p. 339. Gabel [7], pl. 14, figs. 32, 33. "Brizalina earlandi" Küppers [70], p. 129, pl. 5, figs. 13a, b. Note: Despite the findings of Gabel [7] and Küppers [70], Bolivina earlandi was not recorded in the North Sea, Channel and adjacent northeastern Atlantic northward of Ria de Vigo, Spain [118]. The species was particularly reported from cold seep sediments and oil production sites [119-121].

Bolivina pseudoplicata Heron-Allen and Earland 1930 [122], p. 81, pl. 3, figs. 36-40. Gabel [7], pl. 14, figs. 38, 39.
Küppers [70], p. 125, pl. 5, figs. 8-11. Murray [123], p. 19, fig. 5, no. 17.

Bolivina pseudopunctata Höglund 1947 [124], p. 273, pl. 24, fig. 5, pl. 32, figs. 23, 24. Hofker [125], p. 241, pl. 4, fig. 24. "Brizalina pseudopunctata" Küppers [70], p. 130, pl. 5, fig. 14. "Bolivinella pseudopunctata" Gustafsson and Nordberg [126], p. 11, pl. 1, fig. 3. Note: the specimens from Helgoland harbour are smaller than those from Gullmar fjord. The twisted, irregular shape and coarse pores at the lower part of the chamber walls discriminate this taxon from other Bolivina species [127].

Buccella frigida (Cushman)=Pulvinulina frigida Cushman 1922 [128], p. 12, fig. 144. Haake [71], p. 44, pl. 4, figs. 3-6. Feyling-Hansen et al. [129], p. 253, pl. 8, figs. 12-14. Schroeder-Adams et al. [130], p. 24, pl. 8, figs. 10,11.

Buliminella elegantissima $\quad($ 'Orbigny $)=$ Bulimina elegantissima d'Orbigny 1839 [105], p. 51, pl. 7, figs. 13, 14. Haake [71], p. 34, pl. 2, figs. 1, 2. Murray [104], p. 41, fig. 11, nos. K, L. "Buliminella borealis" Müller-Navarra et al. [4], p. 74, fig. 3, no. 10. Note: Haynes [103] recognised a difference between a spruce-cone shaped North Atlantic and a spindle-shaped Pacific morphotype. The latter is resembling d'Orbigny's [105] species concept. Buliminella borealis was consequently established as new species confined to the Atlantic realm. However, specimens from the Peruvian Oxygen Minimum Zone [e.g., 131, fig. 12.17], are almost identical in shape to the holotype of B. borealis from Caernavon Bay, Wales. Furthermore, Haake [71] recognised both end member morphologies in the same population on tidal flats off Langeoog, southern North Sea. We therefore consider $B$. borealis as junior synonym of Buliminella elegantissima.

Cassidulina laevigata d'Orbigny 1826 [132], p. 282, pl. 15, figs. 4, 5. Feyling-Hansen et al. [129], p. 246, pl. 7, figs. 20,21, pl. 18, fig. 12. Schiebel [127], p. 39, pl. 2, fig. 11. Murray [123], p. 21, fig. 6, nos. 8-10.

Cibicides lobatulus (Walker and Jacob) $=$ Nautilus lobatulus Walker and Jacob 1798 [133], p. 642, pl. 14, fig. 36. Haynes [103], p. 173, pl. 20, figs. 1-2, fig. 35, nos. 4-10. Horton and Edwards [5], p. 72, pl. 3, figs. 14a-c. Küppers [70], p. 152, pl. 7, figs. 1-3.

Eggerelloides scaber (Williamson)=Bulimina scabra Williamson 1858 [134], p. 65, pl. 5, figs. 136, 137. "Eggerella scabra" Jarke [8], p. 27, pl. 1, figs. 5a-c. "Eggerelloides scabrum" Haynes [103], p. 44, pl. 2, figs. 7, 8, pl. 19, figs. 10, 11, fig. 8, nos.1-4. "Eggerella scabra" de Nooijer [51], pl. 2, fig. B. Note: Eggerelloides scaber is common in the southern North Sea [8], at depths below $20 \mathrm{~m}$ [cf. 135 ], and where the salinity is higher than 24 units during most of the year [67].

Elphidium albiumbilicatum (Weiss) $=$ Nonion pauciloculum Cushman subsp. albiumbilicatum Weiss 1954 
[136], p. 157, pl. 32, figs. 1, 2. "Nonion depressulum forma asterotuberculatum" Haake [71], p. 41, pl. 3, fig. 5. "Cribrononion asklundi" Lutze [52], p. 104, pl. 15, fig. 42. Alve and Murray [75], p. 191, pl. 1, figs. 12, 13. Polovodova et al. [50], p. 141, pl. 1, figs. 17-19. Note: a few, faint bundles of pustules forming chamber projections are bridging the sutures between later chambers. The sutures are markedly curved and incised until close to the margin, whereas the sutural depressions of Haynesina orbicularis are rather straight and terminate in the middle of the chambers. The similar species Elphidium magellanicum Heron-Allen and Earland [137] shows commonly five instead of seven to eight chambers as in E. albiumbilicatum. Their tests are more compressed that in the latter species.

Elphidium clavatum Cushman $=$ Elphidium incertum var. clavatum Cushman 1930 [138], p. 20, pl. 7, fig. 10. "Cribrononion excavatum clavatum" Lutze [52], p. 96, pl. 15, figs. 40, 41. "Elphidium excavatum forma clavata" Miller et al. [139], p. 124, pl. 1, figs. 5, 6, pl. 2, figs. 3-8, pl. 3, figs. 3-8, pl. 4, figs. 1-6, pl. 5, figs. 4-8, pl. 6, figs. 1-5. "Elphidium excavatum clavatum" Schönfeld and Numberger [21], p. 57, pl. 1, figs. 7-9. Darling et al. [140], p. 16, fig. 3-F, no. S4. Note: the circular structure of chamber projections and a knob in the umbilicus is diagnostic for this stout Elphidium. The higher thickness/diameter ratio of ca. 0.5-0.6 discriminates it from Elphidium excavatum [141], which is with ca. 0.4-0.5 slightly more compressed [52]. Both taxa were considered as subspecies based on their different habitats and distribution pattern in the western Baltic Sea [22]. This view has been corroborated by genetic investigations [112]. The dissimilarity to other Elphidium genotypes even justifies the consideration of E. clavatum as individual species [140], which is followed herein.

Elphidium gerthi van Voorthuysen 1957 [142], p. 32, pl. 23, fig. 12. Haake [71], p. 46, pl. 5, fig. 10. "Cribrononion cf. gerthi" Kripner [115], p. 17, pl. 1, figs. 21-24. FeylingHansen et al. [129], p. 274, pl. 11, fig. 14. Nikulina et al. [143], p. 46, pl. 1, figs. 16, 17. Note: the small size, numerous chambers and dense sutural pits, and an umbilical boss or a depression with glossy calcite are diagnostic for this species.

Elphidium incertum (Williamson)=Polystomella umbilicatula var. incerta Williamson 1858 [134], p. 44, pl. 3, fig. 82a. "Cribrononion incertum" Lutze [52], p. 103, pl. 21, figs. 43-44. Haynes [103], p. 199, pl. 22, fig. 6, pl. 24, figs. 14-16, pl. 28, figs. 8, 9. Horton and Edwards [5], p. 76, pl. 4, figs. 18 a, b. Darling et al. [140], p. 17, fig. 3/B, no. S6. Schönfeld [35], p. 388, pl. 1, figs. 1-3, 6-15. Note: the test is rather compressed and shows narrow sutural furrows that are bridged by a few bundles of pustules commonly recognised as chamber extensions. Thereby, they create elongated, slit-like sutural pits. The chamber projections form a circular, shield-alike structure around the umbilicus. Both features are diagnostic for E. incertum.

Elphidium margaritaceum $(\mathrm{Cushman})=$ Elphidium advenum (Cushman) var. margaritaceum Cushman 1930 [138], p. 25, pl. 10, figs. 3a, 3b. Haake [71], p. 49, pl. 5, fig. 11. van Voorthuysen [144], p. 45, pl. 4, figs. 7a, b. Küppers [70], p. 195, pl. 9, figs. 4, 5 .

Elphidium oceanensis d'Orbigny $=$ Polystomella oceanensis d'Orbigny 1826 [132], p. 285, no. 8. "Elphidium gunteri" Haake [71], p. 48, pl. 5, figs. 3, 4. "Elphidium gunteri" Richter [145], p. 345, fig. 7. Alve and Murray [75], p. 190, pl. 1, figs. 14, 15. Austin [146], fig. 6.12 no. 5. Camacho et al. [147], p. 27, fig. 5, nos. 19-21. "Elphidium oceanense" Darling et al. [140], p. 20, fig. 3/F, no. S3. Note: Elphidium gunteri Cole [148] is considered a junior synonym of E. oceanensis [104], p. 52].

Elphidium selseyense $($ Heron-Allen and Earland $)=$ Polystomella striatopunctata var. selseyensis Heron-Allen and Earland 1911 [149], p. 448. Haake [71], p. 49, pl. 5, fig. 15, pl. 6, fig. 1-5 (pars). Hofker [125], p. 257, pl. 8, figs. 8, 9, pl. 9, fig. 1. "Elphidium excavatum selseyense" Langer et al. [90], p. 90, pl. 2, figs. 19-21. "Elphidium excavatum" Müller Navarra et al. [4], p. 74, fig. 3, nos. 17-19. Darling et al. [140], p. 17, fig. 3/F, no. S5. Note: The test is flat, the outline lobate and the chambers are inflated. The sutures are curved backwards and show a few septal bars on later chambers. The depressed umbilical area is covered with pustules and granules. Elphidium selseyense has been considered as one of five ecophenotypes of Elphidium excavatum [141], which is linked to the other formae in an intergradational series [139]. None-the-less, distinct distributional patterns provided evidence for a discrimination of these formae on subspecies or species level [e.g., 145, p. $352 \mathrm{ff}$.]. While E. selseyense is frequent on near shore sands, the genuine $E$. excavatum is found at greater depths in the North Sea [55, 70]. The latter species shows no granules in the umbilical area but thin, pointed chamber extensions [150].

Elphidium voorthuyseni Haake 1962 [71], p. 50, pl. 5, figs. 6, 7. "Elphidium sp." Darling et al. [140], p. 18, fig. $3 / \mathrm{B}$, no. S14. Note: The test shows $8-10$ chambers and is very flat, the outline is almost smooth. The sutures are slightly curved and sharply turning backwards close to the margin. They show 3-5 sutural pits that are very small and indistinct. The umbilicus is almost closed and surrounded by cuspid chamber projections. Haynes [103] examined locotypic specimens and did not recognise a distinctive difference to $E$. incertum, even though the latter is characterised by slit-like sutural openings and a shielded umbilicus. The very similar and yet formally 
undescribed Elphidium sp. was only recorded around Scotland and assigned to genotype S14 [140].

Elphidium waddense van Voorthuysen 1951 [151], p. 25, pl. 2, figs. 16a, b. "Elphidium selseyense" Haake [71], pl. 5, figs. 12-14 (pars, "Extremform 1"). Haynes [103], p. 206, pl. 24, figs. 4, 10. Hofker [125], p. 259, pl. 9, fig. 6. "Elphidium excavatum forma selseyensis" Küppers [70], p. 186, pl. 8, figs. 10a, b. Note: This species has been confused with E. selseyense in the literature, though the tests are rather discoidal than flat with a depressed umbilicus. They are generally smaller than E. selseyense, the sutures are less curved and less depressed, the umbilical area shows either a glassy boss or numerous small granules. The umbilical area and earlier chambers often appear rough or frosty. It has to be noted that SEM images of Elphidium lidoense Cushman [152], applied to genotype S13 [140], depict an umbilical structure very similar to $E$. waddense but show no septal bars as the latter.

Elphidium williamsoni Haynes 1973 [103], p. 207, pl. 27, fig. 7, pl. 25, figs. 6, 9, pl. 27, figs. 1-3. "Elphidium excavatum" Haake [71], p. 47, pl. 5, fig. 5. "Elphidium excavatum "Richter [145], p. 345, figs. 3, 4. "Cribrononion cf. alvarezianum" Lutze [52], p. 101, pl. 15, fig. 46. Langer et al. [90], p. 90, pl. 2, figs. 22-25. Darling et al. [140], fig. 3/A, no. S1. Müller-Navarra et al. [4], p. 74, fig. 3, nos. 20, 21. Roberts et al. [153], p. 8, fig. 2, nos. A-F. Note: Roberts et al. [153] studied and sequenced type specimens and topotypic material as well as syntype specimens of Polystomella umbilicatula Walker and Jacob [133]. Even though the assemblage from the type locality showed a wide morphological variety, a particular combination of morphological characters allowed a secure discernation from the co-occurring E. clavatum and E. selseyense. Genotype $\mathrm{S} 1$ has been assigned to E. williamsoni by Darling et al. [140].

Fissurina lucida $($ Williamson $)=$ Entosolenia marginata var. lucida Williamson 1848 [154], p. 17, pl. 2, fig. 17. Haake [71], p. 38, pl. 2, figs. 11, 12. Hofker [125], p. 239, pl. 4, fig. 17. Gabel [7], pl. 15, figs. 34, 35. Note: Küppers [70] recognised a continuous range of variability between F. lucida and Fissurina laevigata Reuss [155] morphotypes and therefore considered the latter as variant of $F$. lucida. Specimens from tidal flats are about half the size as specimens from deeper waters in the North Sea.

Haynesina depressula (Walker \& Jacob)=Nautilus depressulus Walker and Jacob 1798 [133], p. 641, pl. 14, fig. 33. "Nonion umbilicatulum" Haake [71], p. 41, pl. 3, figs. 3, 4. "Nonion depressulus" Haynes [103], p. 209, pl. 22, figs. 8-11, pl. 29, fig. 9, fig. 44, nos. 1-3. "Nonion depressulus" Horton and Edwards [5], pl. 4, figs. 22a, b. "Nonion depressulum" Hofker [125], p. 254, pl. 8, fig. 3. Darling et al. [140], p. 21, fig. 3/G, no. S17. Note: The tests of $H$. depressula are rather compressed, the margin is acute rather than broadly rounded as in Haynesina germanica [156], and the depressed umbilical area is covered with small granules. The species has been assigned to Haynesina by Banner and Culver [157] due to its possession of short, intercameral lacunae. Genetic data group $H$. depressula specimens to a separate clade $\mathrm{G}$, with a marked difference to another clade $\mathrm{C}$ with $\mathrm{H}$. germanica [140]. Therefore, the genus Haynesina could be polyphyletic.

Haynesina germanica $($ Ehrenberg $)=$ Nonionina german ica Ehrenberg 1840 [158], p. 23. "Nonionina germanica" Ehrenberg [156], pl. 2, figs. 1a-g. "Nonion depressulum" Haake [71], p. 40, pl. 3, figs. 1, 2. "Protelphidium anglicum" Haynes [103], p. 216, pl. 22, figs. 15, 16, pl. 23, figs. 1, 2, pl. 27, figs. 6-9. Langer et al. [90], p. 90, pl. 2, figs. 14-18. 12-14. Darling et al. [140], p. 21, fig. 3/C, no. S16. Müller-Navarra et al. [4], p. 74, fig. 3, nos. Note: The shape is highly variable. Most tests are planspiral involute, some are evolute [e.g., 145, fig. 1]. The umbilicus is depressed or shows an umbilical boss on both sides, which is created by earlier chambers [e.g., 4, fig. 3 no. 13] and oblique coiling [e.g., 35, pl. 1, fig. 23]. Later chambers may be slightly inflated or flush. Minute pustules cover the umbilicus, extend into the intercameral lacunae [e.g., 4, fig. 3 no. 12], and may cover the apertural face of the final chamber [159].

Haynesina orbicularis $($ Brady $)=$ Nonionina orbiculare Brady 1881 [160], p. 415, pl. 21, fig. 5. "Protelphidium orbiculare" Feyling-Hanssen et al. [129], p. 289, pl. 14, figs. 8-11, pl. 24, figs. 6-8. Schröder-Adams et al. [130], p. 32, pl. 8, fig. 9. Pillet et al. [161], p. 13, pl. 1, figs. E-H., Lübbers and Schönfeld [56], pl. 2, figs. 4a-c. Note: the specimens from Japsand are rather small, thin-shelled, and much thicker than $H$. germanica in the same samples. The last whorl shows 4-6 instead of 8-11 chambers as in $H$. germanica. The inflated chambers rapidly increase in size as added [e.g., 56, pl. 2, fig. 4b]. The umbilical area and sutural depressions are covered by small pustules [e.g., 161, pl. 1 fig. F]. This feature, and the low number of chambers is also recognised in Elphidium magellanicum Heron-Allen and Earland [137] but their tests are much more compressed than H. orbicularis.

Hopkinsina pacifica Cushman 1933 [162], p. 86, pl. 8, fig. 16. "Spiroloxostoma sp."-Moodley [163], p. 60, pl. 1, figs. 1-3. Alve and Murray [69], pl. 2, fig. 10. "Hopkinsina atlantica" Debenay et al. [140], pl. 4, fig. 14. de Nooijer [51], pl. 1, fig. J. Note: Cushman [164] introduced a new, atlantica variety of Hopkinsina pacifica by the disjunct distribution of tropical Pacific and Atlantic New England coast, and because the Atlantic specimens showed smaller, twisted and compressed tests with more oblique sutures. In the living assemblage from the North Sea off Helgoland [55], any transitions between twisted and 
compressed tests with oblique sutures and more cylindrical tests with straight sutures were recognised. The cylindrical tests were even smaller than the compressed tests. We therefore consider the atlantica variety of cylindrical specimens with straight sutures as an endmember in the range of morphological variability of $H$. pacifica.

Jadammina macrescens (Brady) = Trochammina inflata var. macrescens Brady 1870 [165], p. 290, pl. 11, figs. 5a-c. "Jadammina polystoma" Haake [71], p. 31, pl. 1, figs. 7-9. Lehmann [6], p. 133, pl. 5, figs. 1, 2. Horton and Edwards [5], p. 66, pl. 1, fig. 4. Müller-Navarra et al. [4], p. 74, fig. 3 , nos. 4, 5. Note: The compressed test, supplementary, tubular apertures on the areal face, the smooth test wall, in which planar agglutinated grains flush with the surface, the almost closed umbilicus and comparatively long, later chambers discriminate this species from Balticammina pseudomacrescens Brönnimann, Lutze and Whittaker [166] or Trochamminita irregularis Cushman and Brönnimann [167].

Labrospira jeffreysii $($ Williamson $)=$ Nonionina jeffreysii Williamson 1858 [134], p. 34, pl. 3, figs. 72, 73. Höglund [124], p.146, pl. 11, fig. 3. "Cribrostomoides jeffreysi" Küppers [70], p. 40, pl. 2, fig. 3. "Cribrostomoides jeffreysii" Murray [123], p. 11, fig. 2, no. 5.

Morulaeplecta bulbosa Höglund 1947 [124], p. 165, pl. 12, fig. 2, text-figs. 142a, b. Murray [123], p. 13, fig. 3, nos. 4,5 . Note: The specimens are very small and the test wall is rather fragile. Fragments may easily be mixed with Textularia earlandi Parker [168]. Therefore, this species is probably scarcely recorded.

Nonion pauperatus $($ Balkwill and Wright $)=$ Nonionina pauperata Balkwill and Wright 1885 [169], p. 353, pl. 13, figs. 25, 26. "Nonion pauperatum" Haake [71], p. 42, pl. 3, figs. 6, 7. "Nonion pauperatum" Gabel [7], pl. 12, figs. 14, 15. "Nonion (Florilus) pauperatum" Haynes [103], pl. 22, figs. 13, 14, pl. 23, fig. 4, fig. 44, nos. 4-7. Murray [123], p. 24, fig. 9, no. 1 .

Nonionella crassesuturalis van Voorthuysen 1958 [170], p. 23. Hofker [125], p. 254, pl. 8, fig. 2. Note: The specimens from Japsand are only half the size as those reported from the Netherlands.

Paratrochammina (Lepidoparatrochammina) haynesi (Atkinson) $=$ Trochammina haynesi Atkinson 1969 [171], p. 529, pl. 6, figs. 1a-c. "Trochammina haynesi" Haynes [103], p. 35, fig. 6. Murray and Alve [31], p. 26, fig. 15, nos. 13, 14. Dorst and Schönfeld [172], p. 173, fig. 2, no. 1, fig. 9 , no. 5 , fig. 10 , no. 4 .

Patellina corrugata Williamson 1858 [134], p. 46, pl. 3, figs. 86-89. Haake [71], p. 43, pl. 3, fig. 9. Küppers [70], p. 83, pl. 4, figs. 5a-c. Murray [123], p. 24, fig. 9, nos. 6, 7.

Planorbulina mediterranensis d'Orbigny 1826 [132], p. 280, pl. 14, figs. 4-6. Jarke [8], pl. 4, figs. 1a-c. Küppers [70], p. 155, pl. 7, fig. 6. Murray [123], p. 24, fig. 9, no.
8. Mendes [173], p. 193, pl. 4, figs. 1a-j. Note: The specimens from Japsand are very small and depict the early ontogenetic phase [e.g., 173, plate 4, fig. 1d-f].

Quinqueloculina seminulum (Linné) $=$ Serpula seminulum Linné 1758 [174], p. 786. “Quinqueloculina seminula" Jarke [8], p. 27, pl. 1, fig. 6. Hofker [125], p. 234, pl. 3, fig. 3. "Quinqueloculina sp." de Nooijer [51], pl. 1, fig. L. Note: This species is abundant in the southern North Sea at salinities of $>24$ permil $[8,125]$. The elongated elliptical and triangular shape, and the rounded chambers with thick walls discriminate Q. seminulum from other Quinqueloculina species.

Stainforthia fusiformis (Williamson) $=$ Bulimina pupoides d'Orbigny var. fusiformis Williamson 1858 [134], p. 63, pl. 5, figs. 129-130. Gooday and Alve [175], figs. 3, 4, pl. 1, figs. H-L, pl. 3, figs. A-J. Alve [176], fig. 1.

Trochammina inflata (Montagu) $=$ Nautilus inflatus Montagu 1808 [177], p. 81, pl. 18, fig. 3. Richter [145], p. 346, fig. 6. Horton and Edwards [5], p. 69, pl. 2, fig. 8a-d. Lehmann [6], p. 141, pl. 4, figs. 10, 11. Müller-Navarra et al. [4], p. 74, fig. 3, nos. 4, 5 .

\section{Supplementary Information}

The online version contains supplementary material available at https://doi. org/10.1186/s10152-021-00551-2.

Additional file 1: Table S1. Foraminiferal census data of the living fauna, Japsand, German Wadden Sea.

Additional file 2: Table S2. Foraminiferal census data of the dead assemblage, Japsand, German Wadden Sea.

Additional file 3: Table S3. Biometric measurements of the most important foraminiferal species from the living fauna, Japsand, German Wadden Sea

Additional file 4: Table S4. Biometric measurements of the most important foraminiferal species from the dead assemblage, Japsand, German Wadden Sea.

Additional file 5: Table S5. Foraminiferal census data of the living fauna from Helgoland inner port.

Additional file 6: Table S6. Foraminiferal census data of the living fauna from the Bay of Tümlau, near Westerhever [4] used for the comparison of locations in this study.

Additional file 7: Table S7. Foraminiferal census data of the living fauna from Schobüll.

\section{Acknowledgements}

We want to thank the team from the "Schutzstation Wattenmeer" at Hallig Hooge for their support by giving the opportunity to join a guided tour to the Japsand. Furthermore, they let us use their facilities for microscopy. Leif Boyens is thanked for his flexibility and his accommodation space. The help of Danny Arndt during fieldwork is gratefully acknowledged. The valuable comments and suggestions of the Editor and two anonymous reviewers helped improving the manuscript a lot.

\section{Authors' contributions}

This study is part of the Ph.D. project of the first author, who collected the samples, processes them in the laboratory, analysed the living fauna, acquired, analysed and interpreted the data. Furthermore, the first author created the 
figures and plates. The second author designed the work concept in part, analysed the foraminifera from the dead assemblage and contributed major to the taxonomic work of this study. Both authors were equal contributors in writing and editing of the manuscript. Both authors read and approved the final manuscript.

\section{Funding}

Open Access funding enabled and organized by Projekt DEAL. The research is funded by GEOMAR Helmholtz Centre for Ocean Research, Kiel.

\section{Availability of data and materials}

All data generated or analysed during this study are included in this published article and its Additional files.

\section{Declarations}

\section{Ethics approval and consent to participate}

Not applicable.

\section{Consent for publication}

Not applicable.

\section{Competing interests}

The authors declare that they have no competing interests.

Received: 16 December 2020 Accepted: 10 September 2021 Published online: 28 September 2021

\section{References}

1. Hofstede JLA. Regional differences in the morphologic behaviour of four German Wadden Sea barriers. Quat Int. 1999;56(1):99-106.

2. Hofstede J. Process-response analysis for the North Frisian supratidal sands (Germany). J Coast Res. 1997:13:1-7.

3. Richter G. Beobachtungen zur Ökologie einiger Foraminiferen des Jade-Gebietes; 1961.

4. Müller-Navarra K, Milker Y, Schmiedl G. Natural and anthropogenic influence on the distribution of salt marsh foraminifera in the Bay of Tümlau, German North Sea. J Foraminifer Res. 2016;46(1):61-74.

5. Horton BP, Edwards RJ. Quantifying Holocene sea level change using intertidal foraminifera: lessons from the British Isles. Departmental Papers (EES); 2006:50.

6. Lehmann G. Vorkommen, Populationsentwicklung Ursache fleckenhafter Besiedlung und Fortpflanzungsbiologie von Foraminiferen in Salzwiesen und Flachwasser der Nord-und Ostseeküste SchleswigHolsteins, Dissertation, University of Kiel; 2000. p. 218.

7. Gabel B. Die Foraminiferen der Nordsee. Helgoländer Meeresun. 1971;22(1):1-65

8. Jarke J. Die Beziehungen zwischen hydrographischen Verhältnissen, Faziesentwicklung und Foraminiferenverbreitung in der heutigen Nordsee als Vorbild für die Verhältnisse während der Miocän-Zeit. Meyniana. 1961:10:21-36.

9. Moodley L, Boschker HTS, Middelburg JJ, Pel R, Herman PMJ, de Deckere $\mathrm{E}$, Heip CHR. Ecological significance of benthic foraminifera: ${ }^{13} \mathrm{C}$ labelling experiments. Mar Ecol Prog Ser. 2000;202:289-95.

10. van Oevelen D, Moodley L, Soetaert K, Middelburg JJ. The trophic significance of bacterial carbon in a marine intertidal sediment: results of an in situ stable isotope labeling study. Limnol Oceanogr. 2006;51:2349-59.

11. Lei YL, Stumm K, Wickham SA, Berninger UG. Distributions and biomass of benthic ciliates, foraminifera and amoeboid protists in marine, brackish and freshwater sediments. J Eukaryote Microbiol. 2014;2014(61):493-508.

12. Nordberg K, Asteman IP, Gallagher TM, Robijn A. Recent oxygen depletion and benthic faunal change in shallow areas of Sannäs Fjord, Swedish west coast. J Sea Res. 2017;127:46-62.

13. Alve E, Korsun S, Schönfeld J, Dijkstra N, Golikova E, Hess S, et al. ForamAMBI: a sensitivity index based on benthic foraminiferal faunas from
North-East Atlantic and Arctic fjords, continental shelves and slopes Mar Micropaleontol. 2016;122:1-12.

14. Duffield CJ, Hess S, Norling K, Alve E. The response of Nonionella iridea and other benthic foraminifera to "fresh" organic matter enrichment and physical disturbance. Mar Micropaleontol. 2015;120:20-30.

15. Asteman IP, Nordberg K. Foraminiferal fauna from a deep basin in Gullmar Fjord: the influence of seasonal hypoxia and North Atlantic Oscillation. J Sea Res. 2013;79:40-9.

16. Dolven JK, Alve E, Rygg B, Magnusson J. Defining past ecological status and in situ reference conditions using benthic foraminifera: a case study from the Oslofjord, Norway. Ecol Indic. 2013;29:219-33.

17. Mendes I, Dias JA, Schönfeld J, Ferreira Ó, Rosa F, Lobo FJ. Living, dead and fossil benthic foraminifera on a river dominated shelf (northern Gulf of (adiz) and their use for paleoenvironmental reconstruction. Cont Shelf Res. 2013;68:91-111.

18. Bouchet VMP, Alve E, Rygg B, Telford RJ. Benthic foraminifera provide a promising tool for ecological quality assessment of marine waters. Ecol Ind. 2012;23:66-75.

19. Mojtahid M, Jorissen F, Lansard B, Fontanier C, Bombled B, Rabouille C. Spatial distribution of live benthic foraminifera in the Rhône prodelta: faunal response to a continental-marine organic matter gradient. Mar Micropaleontol. 2009;70(3-4):177-200.

20. Mojtahid M, Jorissen F, Lansard B, Fontanier C. Microhabitat selection of benthic foraminifera in sediments off the Rhône River mouth (NW Mediterranean). J Foraminfer Res. 2010;40(3):231-46.

21. Schönfeld J, Numberger $L$. The benthic foraminiferal response to the 2004 spring bloom in the western Baltic Sea. Mar Micropaleontol. 2007;65(1-2):78-95.

22. Lutze G. Foraminiferen der Kieler Bucht (Westliche Ostsee): 1. "Hausgartengebiet" des Sonderforschungsbereiches 95 der Universität Kiel. Meyniana. 1974;26:9-22.

23. Bertlich J, Nürnberg D, Hathorne EC, de Nooijer LJ, Mezger EM, Kienast $\mathrm{M}$, et al. Salinity control on Na incorporation into calcite tests of the planktonic foraminifera Trilobatus sacculifer-evidence from culture experiments and surface sediments. Biogeosciences. 2018;15(20):5991-6018.

24. Wit JC, de Nooijer $L J$, Wolthers M, Reichart G-J. A novel salinity proxy based on Na incorporation into foraminiferal calcite. Biogeosciences. 2013;10:6375-87.

25. Elderfield H, Yu J, Anand P, Kiefer T, Nyland B. Calibrations for benthic foraminiferal $\mathrm{Mg} / \mathrm{Ca}$ paleothermometry and the carbonate ion hypothesis. Earth Planet Sci Lett. 2006:250(3-4):633-49.

26. Nürnberg D. Magnesium in tests of Neogloboquadrina pachyderma sinistral from high northern and southern latitudes. J Foraminifer Res. 1995;25(4):350-68.

27. Keul N, Langer G, Thoms S, de Nooijer $\sqcup$, Reichart G-J, Bijma J. Exploring foraminiferal $\mathrm{Sr} / \mathrm{Ca}$ as a new carbonate system proxy. Geochim Cosmochim Acta. 2017;202:374-86.

28. Keul N, Langer G, de Nooijer LJ, Bijma J. Effect of ocean acidification on the benthic foraminifera Ammonia sp. is caused by a decrease in carbonate ion concentration. Biogeosciences. 2013;10(10):6185-98.

29. Ni Y, Foster GL, Bailey T, Elliott T, Schmidt DN, Pearson P, et al. A core top assessment of proxies for the ocean carbonate system in surfacedwelling foraminifers. Paleoceanography. 2007. https://doi.org/10.1029/ 2006PA001337.

30. Bijma J, Spero HJ, Lea DW. Reassessing foraminiferal stable isotope geochemistry: impact of the oceanic carbonate system (experimental results). In: Use of proxies in paleoceanography. Berlin: Springer; 1999. p. 489-512.

31. Alve E, Murray JW, Skei J. Deep-sea benthic foraminifera, carbonate dissolution and species diversity in Hardangerford, Norway: an initial assessment. Estuar Coast Shelf Sci. 2011;92(1):90-102.

32. Berkeley A, Perry CT, Smithers SG, Horton BP, Taylor KG. A review of the ecological and taphonomic controls on foraminiferal assemblage development in intertidal environments. Earth Sci Rev. 2007:83(3-4):205-30.

33. Boltovskoy E, Wright R. Ecology. In: Recent foraminifera. Dordrecht: Springer; 1976. p. 223-74.

34. Murray JW. Ecology and applications of benthic foraminifera. Cambridge: Cambridge University Press; 2006. 
35. Schönfeld J. Monitoring benthic foraminiferal dynamics at Bottsand coastal lagoon (western Baltic Sea). J Micropalaeontol. 2018;37(1):383-93.

36. Weinmann AE, Goldstein ST. Changing structure of benthic foraminiferal communities: implications from experimentally grown assemblages from coastal Georgia and Florida, USA. Mar Ecol. 2016;37(4):891-906.

37. Uthicke S, Momigliano P, Fabricius KE. High risk of extinction of benthic foraminifera in this century due to ocean acidification. Sci Rep. 2013;3(1):39.

38. Haynert K, Schönfeld J, Riebesell U, Polovodova I. Biometry and dissolution features of the benthic foraminifer Ammonia aomoriensis at high $\mathrm{pCO}_{2}$. Mar Ecol Prog Ser. 2011;432:53-67.

39. Milker Y, Horton BP, Nelson AR, Engelhart SE, Witter RC. Variability of intertidal foraminiferal assemblages in a salt marsh, Oregon, USA. Mar Micropaleontol. 2015;118:1-16.

40. Leorri E, Gehrels WR, Horton BP, Fatela F, Cearreta A. Distribution of foraminifera in salt marshes along the Atlantic coast of SW Europe: tools to reconstruct past sea-level variations. Quat Int. 2010;221(1-2):104-15.

41. Haslett SK, Strawbridge F, Martin NA, Davies CFC. Vertical saltmarsh accretion and its relationship to sea-level in the Severn Estuary, UK: an investigation using foraminifera as tidal indicators. Estuar Coast Shelf Sci. 2001;52(1):143-53.

42. Edwards RJ, Horton BP. Reconstructing relative sea-level change using UK salt-marsh foraminifera. Mar Geol. 2000;169(1-2):41-56.

43. Hayward BW, Grenfell HR, Scott DB. Tidal range of marsh foraminifera for determining former sea-level heights in New Zealand. NZ J Geol Geophys. 1999;42(3):395-413.

44. Thomas E, Varekamp JC. Paleo-environmental analyses of marsh sequences (Clinton, Connecticut): evidence for punctuated rise in relative sealevel during the latest Holocene. J Coast Res. 1991;1991:125-58.

45. Murray JW, Alve E. Natural dissolution of modern shallow water benthic foraminifera: taphonomic effects on the palaeoecological record. Palaeogeogr Palaeoclimatol Palaeoecol. 1999;146(1-4):195-209.

46. Green MA, Aller RC, Aller JY. Carbonate dissolution and temporal abundances of foraminifera in Long Island Sound sediments. Limnol Oceanogr. 1993;38(2):331-45.

47. Murray JW. Syndepositional dissolution of calcareous foraminifera in modern shallow-water sediments. Mar Micropaleontol. 1989;15(1-2):117-21.

48. Douglas RG, Liestman J, Walch C, Blake G, Cotton ML. The transition from live to sediment assemblage in benthic foraminifera from the southern California borderland. Department of Geological Sciences, University of Southern California Los Angeles; 1980.

49. Schönfeld J, Alve E, Geslin E, Jorissen F, Korsun S, Spezzaferri S. The FOBIMO (FOraminiferal Blo-MOnitoring) initiative-towards a standardised protocol for soft-bottom benthic foraminiferal monitoring studies. Mar Micropaleontol. 2012;94:1-13.

50. Polovodova I, Nikulina A, Schönfeld J, Dullo W-C. Recent benthic foraminifera in the Flensburg Fjord (western Baltic Sea). J Micropalaeontol. 2009;28(2):131-42.

51. de Nooijer LJ. Shallow water benthic foraminifera as proxy for natural versus human-induced environmental change. Utrecht: Utrecht University; 2007.

52. Lutze G. Zur Foraminiferen-Fauna der Ostsee. Meyniana. 1965:15:75-142.

53. Lutze G, Altenbach A. Technik und Signifikanz der Lebendfärbung benthischer Foraminiferen mit Bengalrot. Geologisches Jahrbuch. Reihe A, Allgemeine und regionale Geologie BR Deutschland und Nachbargebiete, Tektonik, Stratigraphie, Paläontologie. 1991(128):251-65.

54. Wefer G. Umwelt, Produktion und Sedimentation benthischer Foraminiferen in der westlichen Ostsee; 1976.

55. Schönfeld J, Golikova E, Korsun S, Spezzaferri S. The Helgoland experiment-assessing the influence of methodologies on recent benthic foraminiferal assemblage composition. London: Geological Society of London; 2013.

56. Lübbers J, Schönfeld J. Recent saltmarsh foraminiferal assemblages from Iceland. Estuar Coast Shelf Sci. 2018;200:380-94.

57. Parent B, Barras C, Jorissen F. An optimised method to concentrate living (Rose Bengal-stained) benthic foraminifera from sandy sediments by high density liquids. Mar Micropaleontol. 2018;144:1-13.
58. Hammer $\varnothing$, Harper DAT, Ryan PD. PAST: paleontological statistics software package for education and data analysis. Palaeontol Electron. 2001;4(1):9.

59. Haake F-W. Zum Jahresgang von Populationen einer Foraminiferen-Art in der westlichen Ostsee. Meyniana. 1967;17:13-27.

60. Gooday AJ. A response by benthic foraminifera to the deposition of phytodetritus in the deep sea. Nature. 1988;332(6159):70-3.

61. Bradshaw JS. Preliminary laboratory experiments on ecology of foraminiferal populations. Micropaleontology. 1955;1:351-8.

62. Murray JW, Alve E. Major aspects of foraminiferal variability (standing crop and biomass) on a monthly scale in an intertidal zone. J Foraminifer Res. 2000;30(3):177-91.

63. Otto GH. A modified logarithmic probability graph for the interpretation of mechanical analyses of sediments. J Sediment Res. 1939;9(2):62-76.

64. Schönfeld J, Voigt T. Sediment geometry, facies analysis and palaeobathymetry of the Schrammstein Formation (upper Turonian-lower Coniacian) in southern Saxony, Germany. Zeitschrift der Deutschen Gesellschaft für Geowissenschaften. 2020;171(2):199-209.

65. Heinz P, Marten RA, Linshy VN, Haap T, Geslin E, Köhler H-R. 70 kD stress protein (Hsp70) analysis in living shallow-water benthic foraminifera. Mar Biol Res. 2012;8(7):677-81.

66. Lutze GF, Wefer G. Habitat and asexual reproduction of Cyclorbiculina compressa (ORBIGNY), Soritidae. J Foraminifer Res. 1980;10(4):251-60.

67. Lutze GF. Siedlungs-Strukturen rezenter Foraminiferen. Meyniana. 1968;18:31-4.

68. Murray JW. Comparative studies of living and dead benthic foraminiferal distributions. In: Hedley RH, Adams CG, editors. Foraminifera, vol. 2. New York: Academic Press; 1976. p. 45-109.

69. Alve E, Murray JW. Temporal variability in vertical distributions of live (stained) intertidal foraminifera, southern England. J Foraminifer Res. 2001;31(1):12-24

70. Küppers R. Zur Foraminiferenfauna bei Helgoland, Dissertation, Universität Bonn; 1987. p. 303.

71. Haake F-W. Untersuchungen an der Foraminiferen-Fauna im Wattgebiet zwischen Langeoog und dem Festland. Meyniana. 1962;12:25-64.

72. Rogerson M, Schönfeld J, Leng MJ. Qualitative and quantitative approaches in palaeohydrography: a case study from core-top parameters in the Gulf of Cadiz. Mar Geol. 2011;280(1-4):150-67.

73. Guimerans PV, Currado JC. Distribution of Planorbulinacea (benthic foraminifera) assemblages in surface sediments on the northern margin of the Gulf of Cadiz. Boletin-Instituto Espanol de Oceanografia. 1999;15(1/4):181-90.

74. Murray JW. Recent benthic foraminiferids of the Celtic Sea. J Foraminifer Res. 1979;9(3):193-209.

75. Alve E, Murray JW. Marginal marine environments of the Skagerrak and Kattegat: a baseline study of living (stained) benthic foraminiferal ecology. Palaeogeogr Palaeoclimatol Palaeoecol. 1999;146(1-4):171-93.

76. Murray JW, Sturrock S, Weston J. Suspended load transport of foraminiferal tests in a tide-and wave-swept sea. J Foraminifer Res. 1982;12(1):51-65.

77. Hayward BW, Grenfell HR, Sandiford A, Shane PR, Morley MS, Alloway BV. Foraminiferal and molluscan evidence for the Holocene marine history of two breached maar lakes, Auckland, New Zealand. NZ J Geol Geophys. 2002;45(4):467-79.

78. Grabert B. Zur Eignung von Foraminiferen als Indikatoren für Sandwanderung. Deutsche Hydrografische Zeitschrift. 1971;24(1):1-14.

79. Kitazato $\mathrm{H}$. Ecology of benthic foraminifera in the tidal zone of a rocky shore. Revue de paléobiologie. 1988:815-25.

80. Schönfeld J. Recent benthic foraminiferal assemblages in deep highenergy environments from the Gulf of Cadiz (Spain). Mar Micropaleontol. 2002;44(3-4):141-62.

81. Hansen A, Knudsen KL. Recent foraminiferal distribution in Freemansundet and Early Holocene stratigraphy on Edgeøya, Svalbard. Polar Res. 1995;14(2):215-38.

82. Murray JW. Living and dead Holocene foraminifera of Lyme Bay, southern England. J Foraminifer Res. 1986;16(4):347-52.

83. Conradsen K. Recent benthic foraminifera in the southern Kattegat, Scandinavia: distributional pattern and controlling parameters. Boreas. 1993;22(4):367-82. 
84. Thomas E, Gapotchenko T, Varekamp JC, Mecray EL, Brink B. Benthic foraminifera and environmental changes in Long Island Sound. J Coast Res. 2000;16:641-55.

85. Knudsen KL. Marine interglacial deposits in the Cuxhaven area, NW Germany: a comparison of Holsteinian, Eemian and Holocene foraminiferal faunas. E\&G Quat Sci J. 1988;38(1):69-77.

86. Knudsen $\mathrm{KL}$. Foraminiferal stratigraphy of quaternary depos its in the Roar, Skjold and Dan fields, central North Sea. Boreas. 1985:14(4):311-24.

87. Konradi PB. Foraminifera in Eemian deposits at Stensigmose, southern Jutland. Dan Geol Unders. 1976;105:1-57.

88. Bird C, Schweizer M, Roberts A, Austin WEN, Knudsen KL, Evans KM, et al. The genetic diversity, morphology, biogeography, and taxonomic designations of Ammonia (foraminifera) in the Northeast Atlantic. Mar Micropaleontol. 2020;155:101726.

89. Fish PR, Whiteman CA. Chalk micropalaeontology and the provenancing of middle Pleistocene lowestoft formation till in eastern England. Earth Surf Process Landf. 2001;26:953-70.

90. Langer $M$, Hottinger L, Huber B. Functional morphology in low-diverse benthic foraminiferal assemblages from tidal flats of the North Sea. Senckenb Marit. 1989;20(3-4):81-99.

91. Lopez E. Algal chloroplasts in the protoplasm of three species of benthic foraminifera: taxonomic affinity, viability and persistence. Mar Biol. 1979;53(3):201-11.

92. Jauffrais T, LeKieffre C, Koho KA, Tsuchiya M, Schweizer M, Bernhard $\mathrm{JM}$, et al. Ultrastructure and distribution of kleptoplasts in benthic foraminifera from shallow-water (photic) habitats. Mar Micropaleontol. 2018;138:46-62.

93. Goldstein ST, Richardson EA. Fine structure of the foraminifer Haynesina germanica (Ehrenberg) and its sequestered chloroplasts. Mar Micropaleontol. 2018;138:63-71.

94. LeKieffre C, Spangenberg JE, Mabilleau G, Escrig S, Meibom A, Geslin E. Surviving anoxia in marine sediments: the metabolic response of ubiquitous benthic foraminifera (Ammonia tepida). PLoS ONE. 2017;12(5):e0177604.

95. Debenay J-P, Bénéteau E, Zhang J, Stouff V, Geslin E, Redois F, et al. Ammonia beccarii and Ammonia tepida (foraminifera): morphofunctional arguments for their distinction. Mar Micropaleontol. 1998;34(3-4):235-44.

96. Bouchet VMP, Debenay J-P, Sauriau P-G. First report of Quinqueloculina carinatastriata (foraminifera) along the French Atlantic coast (MarennesOléron Bay and Ile de Ré). J Foraminifer Res. 2007:37(3):204-12.

97. Gollasch S, MacDonald E, Belson S, Botnen H, Christensen JT, Hamer JP, et al. Life in ballast tanks. In: Invasive aquatic species of Europe. Distribution, impacts and management. Dordrecht: Springer; 2002. p. 217-31.

98. McGann M, Sloan D, Cohen AN. Invasion by a Japanese marine microorganism in western North America. Hydrobiologia. 2000;421(1):25-30.

99. Guy-Haim T, Hyams-Kaphzan O, Yeruham E, Almogi-Labin A, Carlton JT. A novel marine bioinvasion vector: ichthyochory, live passage through fish. Limnol Oceanogr Lett. 2017;2(3):81-90.

100. Debenay J-P, Sigura A, Justine J-L. Foraminifera in the diet of coral reef fish from the lagoon of New Caledonia: predation, digestion, dispersion. Rev Micropaléontol. 2011:54(2):87-103.

101. Alve E, Goldstein ST. Dispersal, survival and delayed growth of benthic foraminiferal propagules. J Sea Res. 2010;63(1):36-51.

102. Ellis BF, Messina AR. Cataloque of foraminifera. New York: Micropaleontology Press. http://www.micropress.org. 1940.

103. Haynes JR. Cardigan Bay recent foraminifera: bulletin of the British Museum (Natural History). Zoology, Supplement 4. British Museum London; 1973.

104. Murray JW. British nearshore foraminiferids. London: Academic Press; 1979

105. d'Orbigny A. Foraminiféres. Voyage dans l'Amerique Méridionale. P. Bertrand, Paris and Strasbourg. 1839;5(5):1-86.

106. Hofker J. The foraminifera of the Siboga expedition. Part III. SibogaExpeditie, Monographie IVa. 1951:1-513.

107. Cushman JA. Recent foraminifera from Porto Rico. Publications of the Carnegie Institution of Washington. 1926;342:73-84.

108. Hayward BW, Buzas MA, Buzas-Stephens P, Holzmann M. The lost types of Rotalia beccarii var. tepida Cushman 1926. J Foraminifer Res. 2003:33(4):352-4
109. Hayward BW, Holzmann M, Grenfell HR, Pawlowski J, Triggs CM. Morphological distinction of molecular types in Ammonia-towards a taxonomic revision of the world's most commonly misidentified foraminifera. Mar Micropaleontol. 2004;50(3-4):237-71.

110. Richirt J, Schweizer M, Bouchet VMP, Mouret A, Quinchard S, Jorissen FJ. Morphological distinction of three Ammonia phylotypes occurring along European coasts. J Foraminfer Res. 2019;49(1):76-93.

111. Asano K. Part 14. Rotaliidae. In: Stach LW, editor. Illustrated catalogue of Japanese tertiary smaller foraminifera. Tokyo: Hosokawa Printing; 1951. p. 1-21.

112. Schweizer M, Polovodova I, Nikulina A, Schönfeld J. Molecular identification of Ammonia and Elphidium species (foraminifera, Rotaliida) from the Kiel Fjord (SW Baltic Sea) with rDNA sequences. Helgol Mar Res. 2011;65(1):1-10.

113. Richter $\mathrm{G}$. Faziesbereiche rezenter und subrezenter Wattensedimente nach ihren Foraminiferen-Gemeinschaften. Senckenb Lethaea. 1967;48:291-335.

114. Heron-Allen E, Earland A. The foraminifera of the West of Scotland. Collected by Prof. WA Herdman, FRS, on the Cruise of the SY'Runa,'JulySept. 1913. Being a Contribution to 'Spolia Runiana... Trans Linnean Soc Lond 2nd Ser Zool. 1916;11(13):197-299.

115. Kripner J. Zur Foraminiferen-Fauna im Wattenmeer bei Sylt. Kiel: Christian-Albrechts-Universität; 1965.

116. Murray JW, Alve E. The distribution of agglutinated foraminifera in NW European seas: baseline data for the interpretation of fossil assemblages. Palaeontol Electron. 2011;14(2):1-41.

117. Parr WJ. Foraminifera. Reports of the British, Australian and New Zealand Antarctic research expedition 1929-31, Series B. Zoology and Botany. 1950;5:232-392.

118. Diz P, Francés G, Costas S, Souto C, Alejo I. Distribution of benthic foraminifera in coarse sediments, Ría de Vigo, NW Iberian margin. J Foraminifer Res. 2004;34(4):258-75.

119. Robinson CA, Bernhard JM, Levin LA, Mendoza GF, Blanks JK. Surficial hydrocarbon seep infauna from the Blake Ridge (Atlantic Ocean, 2150 m) and the Gulf of Mexico (690-2240 m). Mar Ecol. 2004;25(4):313-36.

120. Levin LA. Ecology of cold seep sediments: interactions of fauna with flow, chemistry, and microbes. Oceanogr Mar Biol Annu Rev. 2005:43:1-46.

121. Jorissen FJ, Bicchi E, Duchemin G, Durrieu J, Galgani F, Cazes L, et al. Impact of oil-based drill mud disposal on benthic foraminiferal assemblages on the continental margin off Angola. Deep Sea Res Part II Top Stud Oceanogr. 2009:56(23):2270-91.

122. Heron-Allen E, Earland A. The foraminifera of the Plymouth district. J R Microsc Soc. 1930;50(1):46-84.

123. Murray JW. An illustrated guide to the benthic foraminifera of the Hebridean shelf, west of Scotland, with notes on their mode of life. Palaeontol Electron. 2003;5(1):31.

124. Höglund $H$. Foraminifera in the Gullmar Fjord and the Skagerak. Uppsala University. Zoologiska Bidrag. 1947;26:1-328.

125. Hofker J. The foraminifera of Dutch tidal flats and salt marshes. Neth J Sea Res. 1977:11(3-4):223-96.

126. Gustafsson M, Nordberg K. Living (stained) benthic foraminiferal response to primary production and hydrography in the deepest part of the Gullmar Fjord, Swedish West Coast, with comparisons to Hoglund's 1927 material. J Foraminifer Res. 2001;31(1):2-11.

127. Schiebel R. Rezente benthische Foraminiferen in Sedimenten des Schelfes und oberen Kontinentalhanges im Golf von Guinea (Westafrika). Berichte, Reports, Geologisch-Paläontologisches Institut und Museum Christian-Albrechts-Universität Kiel; 51:1-126.

128. Cushman JA. Results of the Hudson Bay expedition, 1920. I. The foraminifera. Contrib Can Biol. 1922;9:135-47.

129. Feyling-Hanssen RW, Jørgensen JA, Knudsen KL, Lykke-Andersen A-L. Late quaternary foraminifera from Vendsyssel, Denmark and Sandnes, Norway. Copenhagen: Geological Society of Denmark; 1971.

130. Schröder-Adams CJ, Cole FE, Medioli FS, Mudie PJ, Scott DB, Dobbin L. Recent Arctic shelf foraminifera; seasonally ice covered vs perennially ice covered areas. J Foraminifer Res. 1990;20(1):8-36.

131. Erdem Z, Schönfeld J. Pleistocene to Holocene benthic foraminiferal assemblages from the Peruvian continental margin. Palaeontol Electron. 2017;20(2, Article Nr. 35A). 
132. d'Orbigny A. Tableau Methodique de la Classe des Cephalopodes. Annales des Sciences Naturelles. 1826;7:96-314 + 245-314.

133. Walker $\mathrm{G}$, Jacob E. Essays on the microscope, 2nd edition with considerable additions and improvements by F. Kanmacher. Dillon and Keeting. Adams, E. (Ed.). 1798; p. 712.

134. Williamson WC. On the recent foraminifera of Great Britain. London: Ray Society; 1858

135. Wang P. Verbreitung der Benthos-Foraminiferen im Elbe-Aestuar. Meyniana. 1983:35:67-83.

136. Weiss L. Foraminifera and origin of the Gardiners Clay (Pleistocene), Eastern Long Island, New York. United States Geological Survey Professional Paper. 1954;254-G:143-63.

137. Heron-Allen E, Earland A. Foraminifera: Part 1. The ice free area of the Falkland Islands and adjacent seas. Discov Rep. 1932;4:291-460.

138. Cushman JA. The foraminifera of the Atlantic Ocean: Part 7. Nonionidae, Camerinidae, Peneroplidae and Alveolinellidae. Bull U S Natl Mus. 1930;104:1-79.

139. Miller AAL, Scott DB, Medioli FS. Elphidium excavatum (Terquem); ecophenotypic versus subspecific variation. J Foraminifer Res. 1982;12(2):116-44.

140. Debenay J-P, Tsakiridis E, Soulard R, Grossel H. Factors determining the distribution of foraminiferal assemblages in Port Joinville Harbor (lle d'Yeu, France): the influence of pollution. Mar Micropaleontol. 2001;43:75-118.

141. Terquem O. Essai sur le classement des animaux qui vivent sur la plage et dans les environs de Dunkerque. Mémoires de la Société Dunkerquoise pour l'Encouragement des Sciences des Lettres et des Arts (1874-1875). 1875;19:405-57.

142. van Voorthuysen JH. Foraminiferen aus dem Eemien (Riss-Würm-Interglazial) in der Bohrung Amersfoort I (Locus typicus). Mededelingen van de Geologische Stichting, Nieuwe Serie. 1957;11:27-39.

143. Nikulina A, Polovodova I, Schönfeld J. Foraminiferal response to environmental changes in Kiel Fjord, SW Baltic Sea. eEarth. 2008;3(1):37-49.

144. van Voorthuysen JH. Foraminiferal ecology in the Ria de Arosa, Galicia, Spain. Zoologische Verhandelingen. 1973;123:3-82.

145. Richter G. Zur Ökologie der Foraminiferen. I. Die Foraminiferen-Gesellschaften des Jadegebietes. Nat Mus. 1964;94(9):343-53.

146. Austin HA. The biology and ecology of benthic foraminifera inhabiting intertidal mudflats. (Ph.D. thesis), University of St Andrews; 2003

147. Camacho SG, de Jesus Moura DM, Connor S, Scott DB, Boski T. Taxonomy, ecology and biogeographical trends of dominant benthic foraminifera species from an Atlantic-Mediterranean estuary (the Guadiana, southeast Portugal). Palaeontol Electron. 2015;18(1):1-27.

148. Cole WS. The Pilocene and Pleistocene foraminifera of Florida, Florida State Geol. Surv Bull. Tallahassee, Florida. 1931;6(34):182-90.

149. Heron-Allen E, Earland A. On the recent and Fossil foraminifera of the Shore-sands of Selsey Bill, Sussex.-VII. Supplement (Addenda et Corrigenda). J R Microsc Soc. 1911;31(3):298-343.

150. Lévy A, Mathieu R, Momeni I, Poignant A, Rosset-Moulinier M, Rouvillois A, et al. Les representants de la famille des Elphidiidae (foraminifires) dans les sables des plages des environs de Dunkerque. Remarques sur les espices de Polystomella signalees par. 0. Terquem. Revue de Micropaleontologie. 1969;12:92-8.

151. van Voorthuysen JH. Recent (and derived Upper Cretaceous) foraminifera of the Netherlands Wadden Sea (tidal flats). Mededelingen van de Geologische Stichting, Nieuwe Serie. 1951;5:23-32.

152. Cushman JA. Three new foraminifera from the Miocene Bowden Marl of Jamaica. Contrib Cushman Found Foraminifer Res. 1936;12:3-5.

153. Roberts A, Austin W, Evans K, Bird C, Schweizer M, Darling K. A new integrated approach to taxonomy: the fusion of molecular and mor phological systematics with type material in benthic foraminifera. PLoS ONE. 2016;11(7):e0158754

154. Williamson WC. On the recent British species of the genus Lagena. Ann Mag Nat Hist. 1848;1(1):1-20.

155. Reuss AV. Neues Foraminiferen aus den Schichten des Österreichischen Tertiärbeckens. Denkschriften der Akademie des Wissenschaften Wein 1850;1:365-90.

156. Ehrenberg CG. Eine weitere Erläuterung des Organismus mehrerer in Berlin lebend beobachterer Polythalamien der Nordsee. Bericht über die zur Bekanntmachung geeigneten Verhandlungen der Königlichen Preussischen Akademie der Wissenschaften zu Berlin. 1840;18-23.

157. Banner FT, Culver SJ. Quaternary Haynesina n. gen. and Paleogene Protelphidium Haynes; their morphology, affinities and distribution. J Foraminifer Res. 1978;8(3):177-207.

158. Ehrenberg CG. Über noch jetzt zahlreich lebende Thierarten der Kreidebildung und den Organismus der Polythalamien. Königliche Akademie der Wissenschaften Berlin, Physik-Mathematik II, Abhandlungen. 1841;1839:81-174.

159. Austin HA, Austin WEN, Paterson DM. Extracellular cracking and content removal of the benthic diatom Pleurosigma angulatum (Quekett) by the benthic foraminifera Haynesina germanica (Ehrenberg). Mar Micropaleontol. 2005;57(3-4):68-73.

160. Brady HB. Notes on some of the reticularian Rhizopoda of the" Challenger"Expedition. Part III. 1. Classification. 2. Further notes on new species. 3. Note on Biloculina mud. Q J Microsc Sci New Ser. 1881:21:31-71.

161. Pillet L, Voltski I, Korsun S, Pawlowski J. Molecular phylogeny of Elphidiidae (foraminifera). Mar Micropaleontol. 2013:103:1-14.

162. Cushman JA. Some new recent foraminifera from the tropical Pacific. Contrib Cushman Lab Foraminifer Res. 1933:9(4):86.

163. Moodley L. Southern North Sea seafloor and subsurface distribution of living benthic foraminifera. Neth J Sea Res. 1990;27(1):57-71.

164. Cushman JA. Foraminifera from the shallow water of the New England Coast. Cushman Lab Foraminifer Res Special Publ. 1944;12:1-37.

165. Brady GS, Robertson D. I.--The Ostracoda and foraminifera of Tidal Rivers with an analysis and descriptions of the foraminifera, by Henry B. Brady, FLS. Ann Mag Nat Hist. 1870;31(6):1-33.

166. Brönnimann P, Lutze GF, Whittaker JE. Balticammina pseudomacrescens, a new brackish water trochamminid from the western Baltic Sea, with remarks on the wall structure. Meyniana. 1989;41:167-77.

167. Cushman JA, Brönnimann P. Some new genera and species of foraminifera from brackish water of Trinidad. Contrib Cushman Lab Foraminifer Res. 1948;24(1):15-21.

168. Parker FL. Foraminiferal distribution in the Long Island Sound-Buzzards Bay area: bulletin of the museum of comparative zoology. Harvard College. 1952;106(10):428-73.

169. Balkwill FP, Wright J. Report on some recent foraminifera found off the coast of Dublin and in the Irish Sea (with Plates XII., XIII., and XIV.). Trans R Irish Acad. 1880;28:317-72.

170. van Voorthuysen JH. Les Foraminiferes mio-pliocènes et quaternaires du Kruisschans. Institut Royal des Sciences Naturelles de Belgique Memoire. 1958:142:1-34.

171. Atkinson $K$. The association of living foraminifera with algae from the littoral zone, south Cardigan Bay, Wales. J Nat Hist. 1969;3(4):517-42.

172. Dorst S, Schönfeld J. Taxonomic notes on recent benthic foraminiferal species of the family Trochamminidae from the Celtic Sea. J Foraminifer Res. 2015;45(2):167-89.

173. Mendes I. Benthic foraminifera as paleo-environmental indicators in the Northern Gulf of Cadiz. (Tese Doutoramento). Universidade do Algarve, Portugal. 2010. p. 242

174. Linné C. Systema naturæ per regna tria naturæ, secundum classes, ordines, genera, species, cum characteribus, differentiis, synonymis, locis. Tomus I. Editio decima, reformata. Laurentii Salvii, Holmiæ. $1758 ; 10: 824$.

175. Gooday AJ, Alve E. Morphological and ecological parallels between sublittoral and abyssal foraminiferal species in the NE Atlantic: a comparison of Stainforthia fusiformis and Stainforthia sp. Prog Oceanogr. 2001;50(1-4):261-83.

176. Alve E. A common opportunistic foraminiferal species as an indicator of rapidly changing conditions in a range of environments. Estuar Coast Shelf Sci. 2003;57(3):501-14

177. Montagu G. Testacea Britannica, or Natural History of British Shells, marine, land, and fresh-water, including the most minute. Supplement, S. Woolmer, Exeter; 1808. p. 183.

\section{Publisher's Note}

Springer Nature remains neutral with regard to jurisdictional claims in published maps and institutional affiliations. 